$11-2013$

\title{
Unfinished Business: Protecting Voting Rights in the Twenty-First Century
}

Gilda R. Daniels

University of Baltimore School of Law, gdaniels@ubalt.edu

Follow this and additional works at: http://scholarworks.law.ubalt.edu/all_fac

Part of the Civil Rights and Discrimination Commons, Election Law Commons, and the Fourteenth Amendment Commons

\section{Recommended Citation}

Unfinished Business: Protecting Voting Rights in the Twenty-First Century, 81 Geo. Wash. L. Rev. 1928 (2013)

This Article is brought to you for free and open access by the Faculty Scholarship at ScholarWorks@University of Baltimore School of Law. It has been accepted for inclusion in All Faculty Scholarship by an authorized administrator of ScholarWorks@University of Baltimore School of Law. For more information, please contact snolan@ubalt.edu. 


\title{
Unfinished Business: Protecting Voting Rights in the Twenty-First Century
}

\author{
Gilda R. Daniels*
}

\begin{abstract}
While minorities have experienced great progress because of the Voting Rights Act, particularly section 5 of the Act, the work to achieve an electoral process free of discrimination remains unfinished. In Shelby County v. Holder, the Supreme Court struck down section 4 of the Act, which provided the coverage formula through which section 5 was implemented. Without section 4, there is no section 5. The historical and contemporaneous discrimination that minorities in states formerly covered under section 5 continue to face is substantial and outpaces that in noncovered states. Scholars cannot divorce the debate surrounding section 5 's constitutionality, which continues even after Shelby County, from its historical role in combating discrimination in voting. Using a comparative framework of a section 5-covered jurisdiction and a noncovered jurisdiction, this Article discusses the impact of the loss of section 4 of the Voting Rights Act after the Supreme Court's decision in Shelby County v. Holder and suggests a path forward.
\end{abstract}

\section{TABLE OF CONTENTS}

INTRODUCTION ......................................... 1929

I. One Step Forward: The Voting Rights Act of

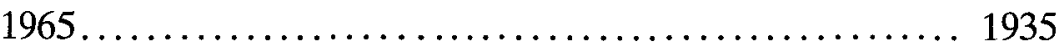

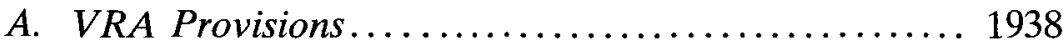

B. VRA Reauthorizations ........................ 1939

C. Challenges to Section $5 \ldots \ldots \ldots \ldots \ldots \ldots \ldots \ldots \ldots . \ldots 1941$

1. Coverage Formula ......................... 1943

2. States' Rights ........................... 1944

II. Two Steps Back: Voter ID ..................... 1947

A. A Tale of Two States ....................... 1949

1. Covered Jurisdiction: Texas ................. 1949

2. Noncovered Jurisdiction: Pennsylvania ......... 1951

III. Solutions That Fit the Problem............... 1954

A. History of Official Discrimination .............. 1955

B. Racially Polarized Voting .................... 1957

C. Preemption Protection ........................ 1959

* Associate Professor of Law, University of Baltimore School of Law. Great thanks to my colleagues at the University of Baltimore for their support; my research assistants, Kenneth Kirkwood, Lakoya Leneir, Jennifer Nwachukwu, Lauren Whitaker, and Gillian Yeadon; and The George Washington Law Review, especially Kathleen Stoughton.

November 2013 Vol. 81 No. 6 


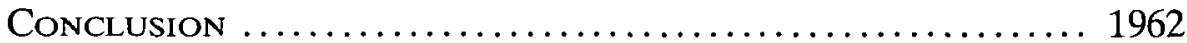

\section{INTRODUCTION}

The right to vote is under assault. ${ }^{1}$ During the 2011-2012 legislative sessions, legislators across the country proposed and passed laws affecting the ability of millions of Americans to effectively register and cast a ballot. ${ }^{2}$ After the sweeping midterm elections of $2010,{ }^{3}$ legislatures focused intently on addressing the contentious issue of voter fraud $^{4}$ through the use of restrictive voter ID laws and other means. ${ }^{5}$ Indeed, the Supreme Court found the possibility of voter fraud sufficient in Crawford v. Marion County Election Board ${ }^{6}$ to justify Indiana's voter ID law. Although addressing voter fraud is a laudable

1 See Gilda R. Daniels, Advancement Project \& Lawyers' Comm. for Civil Rights Under Law, Lining Up: Ensuring Equal access to the Right to Vote (2013), available at http://www.lawyerscommittee.org/admin/site/documents/files/Lining-Up-EnsuringEqual-Access-to-the-Right-to-Vote.pdf (describing the herculean efforts that voters and advocacy groups undertook to address the plethora of challenges to the right to vote during the 2012 election cycle and the new and continued efforts against the right to vote); see also Ryan P. Haygood, The Past as Prologue: Defending Democracy Against Voter Suppression Tactics on the Eve of the 2012 Elections, 64 RutGers L. Rev. 1019, 1060-61 (2012) ("Notwithstanding the vital function it plays in strengthening our democracy, the [Voting Rights Act]-and section 5 in particular-is under heavy attack with constitutional challenges currently before the federal courts. Indeed, there have been more constitutional challenges to section 5 since 2010 than there were in the previous forty-five years of the Act's existence.").

2 See Wendy R. Weiser \& LaWrence Norden, Brennan Ctr. for Justice, Voting Law Changes IN 2012, at 1 (2011) (arguing that an onslaught of legislative bills in the 2011 legislative session would make it harder for nearly five million people to participate in the electoral process).

3 See Jonathan Auerbach \& Deirdre Walsh, Who Are the Key New Republican Leaders?, CNN (Nov. 3, 2010, 1:29 PM), http://www.cnn.com/2010/POLITICS/11/03/new.gop.leaders/index .html (discussing the change in leadership after the 2010 midterm elections).

4 Compare Lorraine C. Minnite, The Myth of Voter Fraud (2010) (arguing that the actual danger of voter fraud is overblown), and WEISER \& NORDEN, supra note 2, at 13 \& n.83 (noting that although Kansas Secretary of State Kris Kobach has claimed 221 allegations of voter fraud in the past thirteen years, those allegations led to only seven convictions, none of which could have been prevented by a photo ID requirement), with How Does Requiring a Voter ID Prevent Election Fraud?, Ask Herrtage, http://www.askheritage.org/how-does-requiring-avoter-id-prevent-election-fraud/ (last visited Sep. 7, 2013) (arguing that voter ID is necessary to combat voter fraud).

5 According to the National Conference of State Legislatures, thirty-four states introduced voter ID legislation in 2011. Voter Identification Requirements, NAT'L Conf. ST. LegisLATURES, http://www.ncsl.org/legislatures-elections/elections/voter-id.aspx (last updated June 27, 2013). In 2012, thirty-two states introduced voter ID legislation, with fourteen passing new voter ID laws. Id. As of April 10, 2013, thirty legislatures had introduced legislation that would affect voter ID requirements. Id.

6 Crawford v. Marion Cnty. Election Bd., 553 U.S. 181 (2008). In Crawford, the Supreme Court found Indiana's voter ID law constitutional. Id at 189. Many states have passed voter ID laws. See Voter Identification Requirements, supra note 5. 
goal, these voter ID laws had a widespread (and predictable) disproportionate impact on Americans who tend to vote Democratic, namely racial and language minorities, the elderly, and young voters. ${ }^{7}$ Restrictive voter identification, voter registration, proof of citizenship laws, and reversals in felon disenfranchisement laws all took a toll on the electorate. ${ }^{8}$ During this push for stricter laws, however, many states, advocacy groups, and others engaged in massive pushback through litigation, referenda, ${ }^{9}$ and the administrative review practice provided for under section 5 of the Voting Rights Act of 1965 ("VRA"). ${ }^{10}$

The VRA itself, particularly section 5 of the Act, is also under assault.11 President Reagan described the right to vote as the "crown

7 See, e.g., Alexander Keyssar, Voter Suppression Returns: Voting Rights and Partisan Practices, HARV. MAG., Jul.-Aug. 2012, at 28, 29 ("The new ID laws have almost invariably been sponsored-and promoted-by Republicans, who claim that they are needed to prevent fraud. (In five states, Democratic governors vetoed ID laws passed by Republican legislatures.)"); Michael Allen, President Bill Clinton Says GOP Voter Suppression Targets Black Churches, Elderly, OpPosing VIEws (Sept. 23, 2012), http://www.opposingviews.com/i/politics/2012-election/ video-pres-bill-clinton-says-gop-voter-suppression-targets-black-churches\#; Dara Kam \& John Lantigua, Former Florida GOP Leaders Say Voter Suppression Was Reason They Pushed New Election Law, PALM BeACH Post (Nov. 25, 2012, 9:58 AM), http://www.palmbeachpost.com/ news/news/state-regional-govt-politics/early-voting-curbs-called-power-play/nTFDy/ (former GOP officials admitted that a law limiting early voting "was intentionally designed ... to inhibit Democratic voters").

8 See Wendy Weiser \& Diana Kasdan, Brennan Ctr. for Justice, Voting Law Changes: Election Update 17-21 (2012), available at http://www.brennancenter.org/sites/ default/files/legacy/publications/Voting_Law_Changes_Election_Update.pdf (surveying these and other voting restrictions implemented before the 2012 election).

9 See id. at 7-11 (updating the progress of combating voter ID laws, including the number of laws that were thwarted through litigation and other means).

1042 U.S.C. $\$ \S 1973-1973 a a-6$ (2006); see also Guidance Concerning Redistricting Under Section 5 of the Voting Rights Act, 76 Fed. Reg. 7470 (Feb. 9, 2011).

11 See infra Part I. These attacks include: Shelby Cnty, v. Holder, 679 F.3d 848 (D.C. Cir. 2012) (challenging the constitutionality of section 5), rev'd, $133 \mathrm{~S}$. Ct. 2612 (2013) (striking down section 4 of the VRA without ruling on the constitutionality of section 5); LaRoque v. Holder, 679 F.3d 905 (D.C. Cir. 2012) (challenging constitutionality of section 5, but the Department of Justice ultimately dismissed the matter, rendering it moot); LaRoque v. Holder, 650 F.3d 777 (D.C. Cir. 2011) (seeking declaratory judgment in response to Attorney General's objection to submitted voting change and challenging constitutionality of section 5); Texas v. Holder, $888 \mathrm{~F}$. Supp. 2d 113 (D.D.C. 2012), vacated and remanded, 133 S. Ct. 2886 (2013) (seeking voter ID declaratory judgment action and challenging constitutionality of section 5); Arizona v. Holder, 839 F. Supp. $2 d 36$ (D.D.C. 2012) (seeking a three-judge court to adjudicate challenge to the constitutionality of section 5 but subsequently withdrawing that challenge, in Stipulation of Dismissal Without Prejudice, Arizona v. Holder, No. 1:11-CV-01559 (D.C. Cir. Apr. 10, 2012)); Florida v. United States, 820 F. Supp. 2d 85 (D.D.C. 2011) (seeking declaratory judgment action preclearing changes in voter registration and early voting, and challenging constitutionality of section 5); Georgia v. Holder, 748 F. Supp. 2d 16 (D.D.C. 2010) (seeking declaratory judgment 
jewel of American liberties,"12 and the VRA has served as a safeguard in protecting American democratic ideals for almost fifty years. ${ }^{13}$ It nonetheless has suffered many blows, including an intense battle in the United States Supreme Court to determine if section 5 is constitutional. ${ }^{14}$

The Supreme Court avoided the constitutional question a few years ago in Northwest Austin Municipal Utility District v. Holder ("NAMUDNO"). ${ }^{15}$ During the oral argument in NAMUDNO, Justice Kennedy stated, "Congress has made a finding that the sovereignty of Georgia is less than the sovereign dignity of Ohio. The sovereignty of Alabama, is less than the sovereign dignity of Michigan. And the governments in one are to be trusted less than the governments in the other." 16 Four years after this warning, the Court sought to attack the constitutional question head-on in Shelby County v. Holder, ${ }^{17}$ in what many believed would be an attempt to finally hold section 5 unconstitutional. ${ }^{18}$ Instead of striking down section 5, however, the Supreme

action preclearing voter registration application changes and alternatively challenging constitutionality of section 5).

12 Ronald Reagan, Pres. of the U.S., Remarks on Signing H.R. 3112 Into Law (June 29, 1982), in 18 WkLy. Compilation Presidential Documents 846, 847 (1982) ("[T] he right to vote is the crown jewel of American liberties, and we will not see its luster diminished."); see also S. REP. No. 109-295, at 1 (2006) ("The Voting Rights Act of 1965 was enacted to remedy 95 years of pervasive racial discrimination in voting, which resulted in the almost complete disenfranchisement of minorities in certain areas of the country. The Act is rightly lauded as the crown jewel of our civil rights laws because it has enabled racial minorities to participate in the political life of the nation. We recognize the great strides that have been made in the treatment of racial minorities over the last forty years, but extending the expiring provisions of the Voting Rights Act is still necessary to continue to fulfill its purpose." (emphasis added) (citation omitted)).

13 The Voting Rights Act: Protecting Voters for Nearly Five Decades, BrenNan CTr. For JUSTICE (Feb. 26, 2013), http://www.brennancenter.org/analysis/voting-rights-act-protectingvoters-nearly-five-decades.

14 Shelby Cnty. v. Holder, 133 S. Ct. 594 (2012) (granting certiorari on "[w] hether Congress' decision in 2006 to reauthorize Section 5 of the Voting Rights Act under the pre-existing coverage formula of Section 4(b) of the Voting Rights Act exceeded its authority under the Fourteenth and Fifteenth Amendments and thus violated the Tenth Amendment and Article IV of the United States Constitution.").

15 Nw. Austin Mun. Util. Dist. No. One v. Holder (NAMUDNO), 557 U.S. 193 (2009) (challenging the constitutionality of section 5 of the VRA).

16 See Transcript of Oral Argument at 34, Nw. Austin Mun. Util. Dist. No. One v. Holder (NAMUDNO), 557 U.S. 193 (2009) (No. 08-322) [hereinafter NAMUDNO Transcript].

17 Shelby Cnty. v. Holder, 133 S. Ct. 2612 (2013).

18 See, e.g., Robert A. Kengle \& Marcia Johnson-Blanco, What Is Next for Section 5 of the Voting Rights Act?, 39 Hum. RTs., Winter 2012, at 9, 12 ("The forthcoming appeals may succeed if the Supreme Court is willing to supplant Congress's judgments about the threat of voting discrimination. However, the gravity of the issues, the powerful decisions by the lower courts that have parsed the record, and the unique level of deference due to Congress when it acts to 
Court held the coverage formula contained in section 4 of the Act unconstitutional. ${ }^{19}$ The effect of the Court's ruling was nevertheless much the same-because section 5 requirements are determined by the section 4 coverage formula struck down by the Court, without section 4 , there is no section $5 . .^{20}$

Although the court found section 4 unconstitutional and consequently rendered section 5 unworkable, it did so without considering the weight of historical voting discrimination in covered jurisdictions and the continued significance of section 5 , the contemporary circumstances that mandate its continuance, and the danger of the old states' rights argument disguised as the "equal sovereignty of the states" doctrine. $^{21}$

With all of the clamor about the end of section 5 prior to the Court's decision, ${ }^{22}$ an important but missing part of the debate concerned what democracy would lose if the Supreme Court dared to find the section 4 coverage formula unconstitutional. Scholars have written about the threat to section 5 and how a Supreme Court decision on its constitutionality could pressure Congress to narrow its scope. ${ }^{23}$

prevent racial voting discrimination all provide compelling reasons for the Supreme Court to approach these cases with restraint.").

19 Section 4 included the coverage formula for section 5 of the Act, which required certain jurisdictions to seek approval of any and all voting changes from the United States Attorney General or the United States District Court for the District of Columbia prior to implementation. The Supreme Court held that the coverage formula was outdated in view of "current conditions" and violated the equal sovereignty of the states. See Shelby Cnty., 133 S. Ct. at 2627-31.

20 The Supreme Court's decision to find section 4's coverage formula unconstitutional means that no previously covered jurisdictions will be required to submit voting law changes to the Department of Justice. The Court indicated that section 5 remained viable if Congress constructs a new coverage formula that considers "current conditions." See id. at 2631.

21 See id. at 2621 ("We explained that $\S 5$ 'imposes substantial federalism costs' and 'differentiates between the States, despite our historic tradition that all the States enjoy equal sovereignty." (emphasis added) (quoting Nw. Austin Mun. Util. Dist. No. One v. Holder (NAMUDNO), 557 U.S. 193, 203-04 (2009))); see also Richard A. Posner, The Voting Rights Act Ruling Is About the Conservative Imagination, SLATE (June 26, 2013, 12:16 AM), http://www .slate.com/articles/news_and_politics/the_breakfast_table/features/2013/supreme_court_2013/ the_supreme_court_and_the_voting_rights_act_striking_down_the_law_is_all.html; John Sides, Race and Voting After the Voting Rights Act: What You Need to Know, WAsh. Post Wonkblog (June 30, 2013, 10:39 AM), http://www.washingtonpost.com/blogs/wonkblog/wp/2013/06/30/raceand-voting-after-the-voting-rights-act-what-you-need-to-know/.

22 See Roger Clegg \& Joshua P. Thompson, Op-Ed., Overturn Unconstitutional Voting Rights Act, WASH. Times, Nov. 14, 2012, at B3; Eric Posner \& Nicholas Stephanopoulos, Don't Worry About the Voting Rights Act, SLATE (Nov. 20, 2012, 3:35 PM), http://www.slate.com/arti cles/news_and_politics/view_from_chicago/2012/11/supreme_court_and_section_5_of_the_voting _rights_act_it_s_ok_to_strike_it.html.

23 See Michael J. Pitts, What Will the Life of Riley v. Kennedy Mean for Section 5 of the Voting Rights Act?, 68 MD. L. Rev. 481, 540 (2009) ("Riley [v. Kennedy, 553 U.S. 406 (2008)] 
They have also written about Congress's authority under the Fourteenth and Fifteenth Amendments to extend section 5.24 Likewise, many reports, law review articles, and editorials sought to analyze the onslaught of legislative attention to election administration issues. ${ }^{25}$ They have not, however, considered the necessity of the Act in light of historical context and modern methods of disenfranchisement. This Article does not debate the characteristics of voter ID-that is, the

may not be just the least dangerous branch of Section 5 jurisprudence; instead, it could be the most dangerous. Riley may represent the harbinger of a new strategy to be implemented by the Court's conservative majority-a strategy that attacks Section 5's procedural prowess rather than the substantive ability of the federal government to deny preclearance. One should not be fooled into thinking that the procedural scope of Section 5 is unimportant. Indeed, the procedural scope of Section 5 may be its most important feature."); Frances E. Faircloth, Comment, The Future of the Voting Rights Act: Lessons from the History of School (Re-)Segregation, 121 YALE L.J. 999, 1000 (2012) (comparing VRA "survival" to desegregation and stating that "if the Court continues to sidestep the question of section 5's validity using the canon of constitutional avoidance, we will be left with a law that is a shadow of its former self. The cause of voting rights might be better served if the Court addressed the constitutional issue head-on, even if that means possibly finding the current section 5 unconstitutional. Such an outcome could motivate Congress to present a more narrowly tailored and carefully crafted provision that would provide the needed protection and would stand up to constitutional scrutiny."); Glenn Kunkes, Note, The Times, They Are Changing: The VRA Is No Longer Constitutional, 27 J.L. \& Pol. 357, 385 (2012) (arguing that the "exceptional circumstances" that required section 5 no longer exist); Richard H. Pildes, Political Avoidance, Constitutional Theory, and the VRA, 117 YALE L.J. Pocket PART 148, 153 (2007), http://www.yalelawjournal.org/images/pdfs/614.pdf.

24 Pamela S. Karlan, Section 5 Squared: Congressional Power to Extend and Amend the Voting Rights Act, 44 Hous. L. Rev. 1, 3-4 (2007) (discussing Congress's power to extend section 5).

25 See, e.g., Keesha Gaskins \& Sundeep Iyer, Brennan Ctr. for Justice, The ChalLENGE OF OBTAINING VOTER IDENTIFICATION (2012), available at http://www.brennancenter .org/sites/default/files/legacy/Democracy/VRE/Challenge_of_Obtaining_Voter_ID.pdf. As early as 2006, the Brennan Center conducted a survey and found that eleven percent of voting age citizens do not have a current government-issued photo ID. Id. at 1 . Other statistics from the report include the following: nearly 500,000 eligible voters lack access to a vehicle and live more than ten miles from a state-issuing office open more than two days a week; in Texas, Hispanic voters are more likely than white voters to lack acceptable forms of ID; and in South Carolina, minorities were almost twenty percent more likely than white voters to not have a photo ID. Id. at 1-2 n.12; see also Election 2012: Voting Laws Roundup, BrenNan CTr. FOR Justice (Oct. 11, 2012), http://www.brennancenter.org/analysis/election-2012-voting-laws-roundup. A 2009 study in Indiana found that of the adult citizen population, $81.4 \%$ of all white eligible adults had a driver's license, compared to only $55.2 \%$ of black eligible adults. It also found that strict photo ID requirements have the greatest impact on the elderly, racial and ethnic minorities, immigrants, those with less educational attainment, and people with lower incomes. See Matt A. Barreto, Stephen A. Nuno \& Gabriel R. Sanchez, The Disproportionate Impact of Voter-ID Requirements on the Electorate-New Evidence from Indiana, 42 PoL. SCI. \& PoL. 111, 113 (2009); see also Matt A. Barreto, Stephen A. Nuno \& Gabriel R. Sanchez, Voter ID Requirements and the Disenfranchisements of Latino, Black and Asian Voters 21 (Sept. 1, 2007) (unpublished manuscript), available at http://faculty.washington.edu/mbarreto/research/Voter_ID_ APSA.pdf. 
voter integrity or voter access debate-that has been discussed extensively elsewhere. ${ }^{26}$ It does not dissect the Supreme Court's Shelby County decision. ${ }^{27}$ It does, however, highlight some glaring omissions from this debate, specifically, the historical need for, and effectiveness of, section 5. This Article uses a covered jurisdiction, Texas, and a noncovered jurisdiction, Pennsylvania, as a framework to illustrate what is lost without section 5 protection. The prism of voter ID laws serves as an exceptional viewpoint to explore the impact of laws on minority citizens and the need for federal oversight. The comparison also shows that "new millennium methods" of voter disenfranchisement have a strong connection to the past and can have a considerable impact on the future of voting. ${ }^{28}$ This Article provides an important analysis discussing the unfinished business of universal suffrage, what is lost if section 5 of the VRA is eliminated, and considerations for Congress in crafting robust voting rights legislation.

This Article demonstrates the importance of placing section 5 in an historical context and understanding the official state-endorsed voter discrimination that gave rise to the VRA, as well as the continued efforts to disenfranchise voters through the use of new millennium methods such as voter ID requirements. This Article stresses the need for section 5's preemptive power to protect citizens from discriminatory voting laws. ${ }^{29}$ This Article is important because it provides a glimpse into a world without section 5 and prescribes measures

26 See, e.g., Christopher S. Elmendorf, Structuring Judicial Review of Electoral Mechanics: Explanations and Opportunities, 156 U. PA. L. REv. 313, 326 (2007) (arguing that courts should return to strict scrutiny); David Schultz, Less than Fundamental: The Myth of Voter Fraud and the Coming of the Second Great Disenfranchisement, 34 WM. MitcheLL L. Rev. 483, 487 (2008); Muhammad At-Tauhidi, Note, Access v. Integrity: Determining the Constitutionality of Voter ID Laws Under Anderson v. Celebrezze, 17 Temp. Pol. \& Civ. RTs. L. Rev. 215, 218 (2007) (arguing for a "least restrictive means standard" in evaluating voter ID laws); Joel A. Heller, Note, Fearing Fear Itself: Photo Identification Laws, Fear of Fraud, and the Fundamental Right to Vote, 62 VAND. L. REV. 1871, 1874 (2009) (addressing the harm of fear-based legislation in the voting context and the lack of a usable standard).

27 For my initial thoughts on the Court's decision, see Gilda R. Daniels, Restore Section 4: What Congress Must Do Now to Protect Voting Rights, AM. Const. Soc'y Blog (July 2, 2013), http:/www.acslaw.org/acsblog/restore-section-4-what-congress-must-do-now-to-protect-votingrights.

28 Gilda R. Daniels, A Vote Delayed Is a Vote Denied: A Preemptive Approach to Eliminating Election Administration Legislation that Disenfranchises Unwanted Voters, 47 U. Louis. VILLE L. REv. 57, 58-59 (2008) (arguing that the abrasive and violent disenfranchising methods of the past are related to the more subtle methods of the new millennium).

29 While the VRA contains other protections, such as section 2, which prohibits racial discrimination in voting, section 5 is still needed for its concentrated and preemptive power. These two provisions have been described as an effective "one-two punch" against discrimination. See J. Morgan Kousser, The Strange, Ironic Career of Section 5 of the Voting Rights Act, 
that legislatures can use to ensure that its voting laws do not disenfranchise citizens.

Part I of this Article provides an overview of the VRA, including its history, reauthorizations, and impact on removing barriers to the vote. Part II will discuss voter ID laws, with an emphasis on recently enacted legislation in Texas and Pennsylvania. The voter ID battles that took place in section 5 and nonsection 5 states are instructive and provide a rationale for why some states are covered and others are not. Part III of this article addresses the arguments against section 5 and provides strong arguments for its restoration, namely the history of state-sanctioned discrimination, racially polarized voting in covered jurisdictions, and the power of preemption. The historical and contemporary discrimination that minorities in section 5-covered states continue to face is substantial and outpaces that in noncovered states. ${ }^{30}$ While minorities have experienced great progress because of the VRA, and particularly section $5,{ }^{31}$ the work to achieve an electoral process free of discrimination remains unfinished.

\section{One Step Forward: The Voting Rights Act of 1965}

The Civil War Amendments, ${ }^{32}$ particularly the Fourteenth and Fifteenth Amendments, were ratified to grant Congress the authority to pass legislation that would preserve the right to participate in the franchise. ${ }^{33}$ However, African Americans, primarily in the former slave states, faced disenfranchisement, threats, and in some cases death even after the ratification of these amendments. ${ }^{34}$ After almost

1965-2007, 86 TEx. L. REv. 667, 721 (2008) (suggesting that sections 2 and 5 work in conjunction to protect voting rights).

30 See infra Part III. VRA).

31 See infra Part III (discussing minority electoral process and other gains due to the

32 The Thirteenth, Fourteenth, and Fifteenth Amendments to the United States Constitution are commonly referred to as the Civil War Amendments. The Thirteenth Amendment abolished slavery and involuntary servitude. U.S. Const, amend. XIII, \& 1 . The Fourteenth Amendment prohibits states from denying "any person within [their] jurisdiction the equal protection of the laws." Id. amend. XIV, $\S 1$. The Fifteenth Amendment grants the right to vote to citizens of the United States regardless of "race, color, or previous condition of servitude." Id. amend. $\mathrm{XV}, \S 1$.

33 Each of these amendments grants Congress the power to enforce it through "appropriate" legislation. Id. amend. XIII, § 2; id. amend. XIV, § 5; id. amend. XV, § 2.

34 The widespread violence and iegal means used to disenfranchise African Americans is well documented. See Kousser, supra note 29, at 678-79 ("[A]fter the [Fifteenth] Amendment went into effect, Democrats gave it the narrowest possible reading and launched a strategy of imposing discriminatory electoral structures, as well as adopting suffrage qualifications that disfranchised those with personal traits thought to be particularly prevalent among African-Ameri- 
a century of ineffective legislation addressing the widespread use of tests, devices, and other obstructions to disenfranchise African Americans, ${ }^{35}$ Congress determined that more focused legislation was needed to enable eligible citizens to vote. ${ }^{36}$ When the civil rights movement focused national attention on this continued infringement of voting rights, Congress responded with the VRA. ${ }^{37}$

The VRA was passed in 1965 to protect the voting rights of minorities, namely African Americans, in the United States. The Act sought to prohibit race discrimination in voting and was a response to the violence and myriad of barriers that Southern obstructionists placed in the way of the right to vote. ${ }^{38}$ The efforts to disenfranchise these voters, including poll taxes and literacy tests, developed after Reconstruction and continued into the $1960 \mathrm{~s}^{39}$ The Attorney General, in his pleas to Congress, argued for comprehensive legislation

cans. . . More practically, the methods testified to the genius of Jim Crow southern politics, which was always to be able to create a new technique to replace one that was not suppressing enough black votes."); see also Tracy Campbell, Deliver the Vote: A History of Election Fraud, an American Political Tradition--1742-2004, at 46-49 (2005) (chronicling the high level of violence intended to intimidate voters in the mid-1800s); ALEXANDER KEYSSar, The Right to Vote: The Contested History of Democracy in the United States 62-63, 77-80, 84-93 (2000) (documenting myriad efforts to disenfranchise African Americans and others including poll taxes, literacy tests, violence, and criminal exclusion laws); RAYFORD W. Logan, The Betrayal of the Negro from Rutherford B. Hayes to Woodrow WilSON 91 (Da Capo Press 1997) (1954) (noting that, in an admission to the widespread post-Reconstruction violence, South Carolina Senator "Pitchfork" Ben Tillman stated, "We have done our level best. . . . [W] have scratched our heads to find out how we could eliminate the last one of them. We stuffed ballot boxes. We shot them . . . We are not ashamed of it.").

35 See Lassiter v. Northampton Cnty. Bd. of Elections, 360 U.S. 45, 50-54 (1959) (holding that literacy tests, if applied equally across all races, did not contravene the Constitution). The VRA subsequently outlawed literacy tests. 42 U.S.C. $\$ 1973$ (b) (2006) (suspending tests or devices).

36 Congress passed the Civil Rights Act of 1957, Pub. L. No. 85-315, 71 Stat. 634, creating the United States Civil Rights Commission and a small Civil Rights Division in the Department of Justice to address the widespread disenfranchisement efforts, but they proved ineffective. J. Morgan Kousser, Colorblind Injustice: Minority Voting Rights and the Undoing of the Second Reconstruction 54 (1999). The Civil Rights Act of 1960, Pub. L. No. 86-449, 74 Stat. 86 , sought to overturn discriminatory registration practices in the South, but lacked effective enforcement provisions. Kousser, supra, at 54.

37 KOUSSER, supra note 36, at 54-55.

38 Michael J. Pitts, The Voting Rights Act and the Era of Maintenance, 59 ALA. L. REv. 903, 909 (2008) ("The Voting Rights Act of 1965 represented the federal government's holistic response to Southern electoral atrocities ... specifically targeting the worst of these government actors with prophylactic measures meant to provide African-Americans the ability to participate on an equal playing field at every step of the registration and balloting process.").

39 In 1966, the United States Supreme Court declared state poll taxes unconstitutional under the Equal Protection Clause of the Fourteenth Amendment in Harper v. Virginia Board of Elections, 383 U.S. 663 (1966). Federal poll taxes were banned by the Twenty-Fourth Amendment. U.S. Const. amend. XXIV, \& 1 . 
that could eliminate the need for piecemeal litigation. ${ }^{40}$ Shortly after passage of the Act, the state of South Carolina petitioned the Supreme Court to render it unconstitutional in South Carolina v. Katzenbach. ${ }^{41}$ In its first challenge, South Carolina argued that section 5 was a gross usurpation of states' rights and that its coverage formula was flawed. ${ }^{42}$ The Supreme Court, however, disagreed. It found that Congress was well within its Fifteenth Amendment power to pass section 5 and charged that the states' rights and awkward coverage formula arguments were "largely beside the point." 43 Furthermore, the Court found that Congress appropriately gathered evidence of racial discrimination in voting and that its coverage formula "evolved to describe these areas [and] was relevant to the problem of voting discrimination, and Congress was therefore entitled to infer a significant danger of the evil" in the covered jurisdictions. ${ }^{44}$ Climactically, it held that "[n]o more was required to justify the application to these areas of Congress' express powers under the Fifteenth Amendment."45 Accordingly, prior to Shelby, each time the Supreme Court has been faced with a challenge to section 5's constitutionality, it has upheld it as a constitutional exercise of congressional authority. ${ }^{46}$ Indeed, even in Shelby, while finding section 4 unconstitutional, the Court decided not to issue an opinion on the constitutionality of section 5.47

40 See Statement of Nicholas Katzenbach, Att'y Gen. of the United States, before the House Judiciary Committee on the Proposed Voting Rights Act of 1965 (March 18, 1965), available at http://www.justice.gov/ag/aghistory/katzenbach/1965/03-18-1965.pdf.

41 South Carolina v. Katzenbach, 383 U.S. 301 (1966).

42 Political scientist J. Morgan Kousser notes:

In its first major Supreme Court test, South Carolina v. Katzenbach, Section 5 was depicted by the southern states that challenged the law as a wholesale bureaucratic intrusion by an all-powerful federal government on its federalist subordinates, the state and local governments. According to the one dissenter in the case, Justice Hugo Black, Section 5 forced the states to come on bended knee to "plead," "beg," and "entreat" with the Attorney General or the district court in Washington, "hundreds of miles away" from their homes, before they could put any change in their own election laws into effect. In an unmistakable reference to the warped reflection of the First Reconstruction that Black must have been exposed to as a boy in Alabama, the Justice declared that Section 5 treated the covered jurisdictions as "conquered provinces."

Kousser, supra note 29, at 683-84 (footnotes omitted).

43 Katzenbach, 383 U.S. at 329.

44 Id. (emphasis added).

45 Id.; see also infra Part III (discussing the present-day states' rights argument).

46 In $N A M U D N O$, the Court avoided the constitutional challenge and found that the bailout procedures needed expanding. See infra Part I.C.

47 Shelby Cnty. v. Holder, 133 S. Ct. 2612, 2631 (2013) ("We issue no holding on $\$ 5$ itself, 


\section{A. VRA Provisions}

The VRA contains two primary provisions: section $2,{ }^{48}$ which is a nationwide prohibition against voting discrimination, and section $5{ }^{49}$ which requires specified covered jurisdictions to submit all voting challenges to either the United States Attorney General or the United States District Court for the District of Columbia. ${ }^{50}$ The VRA also contains temporary provisions that require Congress to periodically reauthorize them..$^{51}$

Under section 5 of the VRA, covered jurisdictions must submit enacted legislation for federal approval in order to implement any voting changes. ${ }^{52}$ Whether the jurisdiction chooses to submit the change to the Attorney General or the District Court for the District of Columbia, it must demonstrate that the submitted change "neither has the purpose nor will have the effect of denying or abridging the right to vote on account of race or color, or [language minority group]." 53 Section 5's preclearance requirement is preemptive because it mandates that a covered jurisdiction demonstrate, prior to the implementation of legislation, that the proposed change is free from any discriminatory purpose or effect..$^{54}$

If a jurisdiction decides to submit the change to the Attorney General, he has sixty days to review the change and either preclear or object. ${ }^{55}$ If the Attorney General does not take any action within the sixty-day period, the change is deemed precleared. Further, if the Attorney General takes an action, his subsequent preclearance or objec-

only on the coverage formula. Congress may draft another formula based on current conditions.").

4842 U.S.C. $\S 1973$ (2006). Section 2 of the VRA prohibits voting practices and procedures that discriminate on the basis of race or color. Traditionally, section 2 cases have involved challenges to at-large methods of election. However, section 2's nationwide prohibition against racial discrimination in voting applies to any voting standard, practice, or procedure, including redistricting plans.

49 Id. \& $1973 \mathrm{c}(\mathrm{a})$.

so $I$ d.

51 See Fannie Lou Hamer, Rosa Parks, and Coretta Scott King Voting Rights Act Reauthorization and Amendments Act of 2006, Pub. L. No. 109-246, 120 Stat. 577. The VRA's most prominent temporary provisions include sections 5 and 203, which govern which jurisdictions must report all voting changes to the Attorney General and designate those jurisdictions required to provide election materials in certain minority languages. 42 U.S.C. § 1973(c) (section 5); 42 U.S.C. § 1973aa-1a (section 203).

52 Voting changes include any practice or procedure affecting the right to vote. See, e.g., Allen v. State Bd. of Elections, 393 U.S. 544, 548-49 (1969) (defining "changes" broadly).

5342 U.S.C. \$ $1973 c(a)$.

54 See id.

55 See 28 C.F.R. § 51.1(a)(2) (2013). 
tion is not subject to judicial scrutiny..$^{56}$ The short review period and the thorough review and analysis that the Attorney General provides allow for the efficient execution of thousands of voting changes per year. ${ }^{57}$

\section{B. VRA Reauthorizations}

The VRA was extended in 1970 and $1975 .{ }^{58}$ It was extended again in $1982,{ }^{59}$ when Congress extended the temporary provisions of the VRA, including section 5.60 Congress, when determining whether to pass the 1982 amendments, discussed the importance of the VRA. ${ }^{61}$ A committee report documenting the 1982 extension evinces that Congress wanted to make sure that "the hard won progress of the past [was] preserved and that the effort to achieve full participation for all Americans in our democracy [would] continue in the future." 62 In 1982, Congress amended section 2,63 extended the language assistance provisions, ${ }^{64}$ and added a section governing assistance to voters who are blind, disabled, or illiterate. ${ }^{65}$

In the 2006 reauthorization, Congress once again extended the temporary provisions of the Act. ${ }^{66}$ These amendments renewed several important provisions, provided for language assistance and Election Day monitors, and continued the requirement for Justice

56 See Morris v. Gressette, 432 U.S. 491, 504-05 (1977) (holding section 5 decisions final and not subject to judicial review).

57 See Notices of Section 5 Activity Under Voting Rights Act of 1965, as Amended, U.S. DEP'T OF JUSTICE, http://www.justice.gov/crt/about/vot/notices/noticepg.php (last visited Sep. 7, 2013) (listing current and archived section 5 submissions).

58 Voting Rights Act Amendments of 1975, Pub. L. No. 94-73, 89 Stat. 400; Voting Rights Act Amendments of 1970, Pub. L. No. 91-285, 84 Stat. 314.

59 Voting Rights Act Amendments of 1982, Pub. L. No. 97-205, 96 Stat. 131.

60 Id. Section 5 is the most challenged provision of the Act. See supra note 11.

61 See S. ReP. No. 97-417, at 1 (1982).

62 Id. at 4.

63 In 1982, Congress eliminated the "intent to discriminate" requirement devised in $\mathrm{Mo}$ bile v. Bolden, 446 U.S. 55 (1980). Voting Rights Act Amendments of 1982, Pub. L. No. 97-205, sec. 3, § 2, 96 Stat. 131, 134 (codified as amended at 42 U.S.C. $\$ 1973$ (2006)).

64 Section 203 of the VRA, another temporary provision of the Act, establishes coverage for jurisdictions with considerable language minorities and requires those jurisdictions, inter alia, to provide election materials and assistance in the covered language. 42 U.S.C. § 1973aa-1a (2006).

65 Section 208 provides that a person who needs assistance in order to vote due to blindness, disability, or illiteracy may have the assistant of their choice, provided that they are not an agent or officer of the voter's employer or union. 42 U.S.C. $\$ 1973$ aa-6.

66 Fannie Lou Hamer, Rosa Parks, and Coretta Scott King Voting Rights Act Reauthorization and Amendments Act of 2006, Pub. L. No. 109-246, secs. 4-5, §§ 4(a)(7)-(8), 5, 120 Stat. 577, 580-81 (codified as amended at 42 U.S.C. $\$ \S 1973 b(a)(7)-(8), 1973 c(b)(2006)$ ) (extending the temporary provisions for another twenty-five years). 
Department preapproval of voting changes. ${ }^{67}$ During the 2006 deliberations, the House committee found that "without the continuation of the Voting Rights Act of 1965 protections, racial and language minority citizens will be deprived of the opportunity to exercise their right to vote, or will have their votes diluted, undermining the significant gains made by minorities in the last 40 years." 68 The committee discussed the importance of the VRA and its protections:

The right to vote is the most fundamental right in our democratic system of government because its effective exercise is preservative of all others. Prior to the enactment of the VRA, parts of the United States condoned the unequal treatment of certain citizens, including denying the most fundamental right of citizenship - the right to vote. The vestiges of such discrimination continue today. In enacting the VRA in 1965, Congress sought to protect the Nation's most vulnerable citizens' right to vote. In renewing and extending the VRA, Congress sought to ensure that even greater numbers of our citizens were protected, including citizens whose primary language is not English, and to ensure that all aspects of the right to vote are protected, including the right to cast a meaningful ballot. ${ }^{69}$

Congress unequivocally found that great progress had been made, but also stressed that the work of section 5 and the VRA was unfinished, stating:

Substantial progress has been made over the last 40 years. Racial and language minority citizens register to vote, cast ballots, and elect candidates of their choice at levels that well exceed those in 1965 and 1982. The success of the VRA is also reflected in the diversity of our Nation's local, State, and Federal Governments. These successes are the direct result of the extraordinary steps that Congress took in 1965 to enact the VRA and in reauthorizing the temporary provisions in $1970,1975,1982$, and $1992 .^{70}$

Congress's desire and authority to renew the temporary provisions were clear. ${ }^{71}$ The congressional record demonstrates the need to

67 Id. at sec. 2, 120 Stat. at 577-78.

68 H.R. REP. No. 109-478, at 2 (2006); see also Pub. L. No. 109-246, sec. 2(b)(9), 120 Stat. at 578 .

69 H.R. ReP. No. 109-478, at 6 (2006) (footnotes omitted).

70 Id.

71 In the 2006 reauthorization, Congress also made what is referred to as "the Ashcroft fix," amending section 5 to overrule the Supreme Court's decisions in Georgia v. Ashcroft, 539 U.S. 461 (2003), which held that states could replace majority-minority districts with "coalition" 
reiterate the historical significance of the Act and highlights the importance of its continued existence. ${ }^{72}$

\section{Challenges to Section 5}

Since its original enactment, Congress has consistently voted to reauthorize the VRA in a bipartisan manner. ${ }^{73}$ As discussed previously, in South Carolina v. Katzenbach the Court addressed both the Fourteenth Amendment and states' rights arguments. ${ }^{74}$ Despite expressing doubts about the constitutionality of section 5 , in NAMUDNO the Court ultimately avoided deciding the constitutional question and instead decided the case on other grounds. ${ }^{75}$

After numerous challenges to section 5's constitutionality, ${ }^{76}$ the Court in Shelby County, while not finding section 5 unconstitutional, came incredibly close in finding that section 4 was unconstitutional. The Court spent a considerable amount of time stressing that requiring some states to submit changes and not others was a "dramatic departure from the principle that all States enjoy equal sovereignty." 77 The Court also stressed that the conditions that existed at the time the formula was devised were a thing of the past, stating: "There is no denying, however, that the conditions that originally justified these measures no longer characterize voting in the covered jurisdictions.

and "influence" districts, id. at 479-80. In doing so, Congress reinstated the "ability to elect" retrogression standard that the Court had previously followed. See Nathaniel Persily, The Promise and Pitfalls of the New Voting Rights Act, 117 YALE L.J. 174, 190 (2007).

72 See Kristen Clarke, The Congressional Record Underlying the 2006 Voting Rights Act: How Much Discrimination Can the Constitution Tolerate?, 43 HARv. C.R.-C.L. L. Rev. 385, 386 (2008) (detailing Congress's "voluminous and extensive" record for the 2006 VRA reauthorization).

73 See Fannie Lou Hamer, Rosa Parks, and Coretta Scot King Voting Rights Act Reauthorization and Amendments Act of 2006, Pub. L. No. 109-246, 120 Stat. 577; Voting Rights Act Amendments of 1982, Pub. L. No. 97-205, 96 Stat. 131; Voting Rights Act Amendments of 1975, Pub. L. No. 94-73, 89 Stat. 400; Voting Rights Act Amendments of 1970, Pub. L. No. 91 285, 84 Stat. 314; see also Nw. Austin Mun. Util. Dist. No. One v. Mukasey, 573 F. Supp. 2d 221, 226-29 (D.D.C. 2008).

74 See supra notes 41-44 and accompanying text; see also Jocelyn Benson, Preparing for 2007: Legal and Legislative Issues Surrounding the Reauthorization of Section 5 of the Voting Rights Act, 67 U. PITT. L. Rev. 125, 137-38 (2005) (discussing dominant arguments challenging section 5, including its constitutionality under the Fourteenth Amendment and its imposition on states' rights).

75 See Nw. Austin Mun. Util. Dist. No. One v. Holder (NAMUDNO), 557 U.S. 193, 204 (2009) ("The Act's preclearance requirements and its coverage formula raise serious constitutional questions under either test.").

76 See supra note 11 for a list of cases that challenged the constitutionality of the Voting Rights Act.

77 Shelby Cnty. v. Holder, 133 S. Ct. 2612, 2618 (2013). 
By 2009 , the racial gap in voter registration and turnout [was] lower in the States originally covered by $\S 5$ than it [was] nationwide." 78

For the majority, the progress made under the Voting Rights Act demonstrated that the extraordinary measure of requiring some states to seek approval for voting changes was no longer needed. The majority did not, however, find that section 5 , which requires those submissions, was unconstitutional. Rather, it ruled that the formula that determines which states must submit voting changes was outdated and stated that Congress must develop "another formula based on current conditions." 79 Justice Ginsburg argued in dissent that the majority usurped Congress's authority and ignored the continuing need for section 5 protection. ${ }^{80}$

Scholars questioned whether section 5 could sustain yet another Supreme Court review and planned for its demise. ${ }^{81}$ Notwithstanding these proclamations, it remains imperative to assess section 5's import and argue for its continued existence in some form.

Section 5 requires that covered jurisdictions explain why proposed voting changes will not place minority voters in a worse position..$^{82}$ This ensures that legislation is duly considered prior to implementation, deterring the enactment of discriminatory legislation in most jurisdictions. ${ }^{83}$ Section 5 places the burden squarely on the

78 Id. at 2618-19 (internal quotation marks omitted).

79 Id. at 2631 ("We issue no holding on $\$ 5$ itself, only on the coverage formula. Congress may draft another formula based on current conditions.").

80 Id. at 2650 (Ginsburg, J., dissenting) ("Throwing out preclearance when it has worked and is continuing to work to stop discriminatory changes is like throwing away your umbrella in a rainstorm because you are not getting wet.").

81 See, e.g., Richard L. Hasen, Congressional Power to Renew the Preclearance Provisions of the Voting Rights Act After Tennessee v. Lane, 66 OHIo ST. L.J. 177, 180 (2005) (discussing Congress's authority to extend section 5 of the Voting Rights Act); Samuel Issacharoff, Is Section 5 of the Voting Rights Act a Victim of Its Own Success?, 104 Colum. L. Rev. 1710, 1710 (2004); Kunkes, supra note 23, at 373 ("A sweeping prophylactic remedy like Section 5 cannot be sustained on sporadic incidents of intentional discrimination in covered jurisdictions. Instead, the first generation barriers of intentional discrimination relied on by Congress in 1965 to justify Section 5 are the main evidence needed to warrant the retention of the preclearance obligation."). But see Karlan, supra note 24, at 4 (arguing that the Civil War Amendments, as well as the Elections and Equal Protection Clauses, provide reinforcement for the VRA's constitutionality); Michael J. Pitts, Let's Not Call the Whole Thing Off Just Yet: A Response to Samuel Issacharoff's Suggestion to Scuttle Section 5 of the Voting Rights Act, 84 Neb. L. REv. 605, 629 (2005); Victor Andres Rodríguez, Comment, Section 5 of the Voting Rights Act of 1965 After Boerne: The Beginning of the End of Preclearance?, 91 CAL. L. REV. 769, 806-11 (2003).

82 Beer v. United States, 425 U.S. 130, 141 (1976) (holding that a proposed plan is retrogressive under section 5 if its net effect would be to reduce minority voters" "effective exercise of the electoral franchise" when compared to the existing voting practice or procedure).

83 Nathaniel Persily, The Promise and Pitfalls of the New Voting Rights Act, 117 YALE L.J. 
submitting jurisdiction rather than the Attorney General or the harmed group. ${ }^{84}$ This burden should force jurisdictions to recognize the importance of drafting legislation that does not hamper the right to vote or impose unreasonable burdens on historically disenfranchised minorities. ${ }^{85}$ The obligation to demonstrate that the legislation does not infringe on the right to vote or disproportionately burden historically disenfranchised minorities is not an onerous one, particularly when we consider the cost of denying the franchise to eligible citizens.

\section{Coverage Formula}

Section 4 of the VRA determined which states or other jurisdictions were "covered" under section 5.86 Section 5 preclearance requirements apply to states and political subdivisions that maintained a "test or device" or had less than fifty percent voter registration or turnout in the 1964 presidential election. ${ }^{87}$ Congress has previously altered the formula through amendments, and the Department of Justice's enforcement of section 4's bailout provision has allowed previously covered jurisdictions to remove themselves from the purview of section 5.88 This view is consistent with Supreme Court precedent as the formula continues to adapt to contemporary circumstances and

174, 199-202 (2007) (arguing that section 5 deters covered jurisdictions from adopting overtly discriminatory legislation).

84 See Procedures for the Administration of Section 5 of the Voting Rights Act of 1965, As Amended, 28 C.F.R. $\$ 51$ (2012).

85 See Kousser, supra note 29, at 768 ("In practical terms, Section 5 has never been much of a burden: at the beginning because it was not enforced and more recently because compliance with it has been built into simple bureaucratic routines-another, rather-easy form to fill out, now online."); Persily, supra note83.

8642 U.S.C. \& $1973 \mathrm{~b}(\mathrm{~b})(2006)$.

87 Currently, covered jurisdictions include all or part of the following states: Alabama, Alaska, Arizona, California, Florida, Georgia, Louisiana, Mississippi, New York, North Carolina, South Carolina, South Dakota, Texas, and Virginia. It also covers select townships in Michigan. Section 5 Covered Jurisdictions, U.S. DEP'T OF JuSTICE, http://www.justice.gov/crt/about/ vot/sec_5/covered.php (last visited Sep. 7, 2013).

88 Congress changed the bailout provisions in 1982 to allow more jurisdictions to seek to use the procedure. In NAMUDNO, the Supreme Court expanded the ability to seek release from section 5's requirements through use of the bailout provision. Nw. Austin Mun. Util. Dist. No. One v. Holder (NAMUDNO), 557 U.S. 193, 210-11 (2009). Since 1967, more than fifty jurisdictions have successfully "bailed out" of section 5 . For a list of jurisdictions and requirements, see Section 4 of the Voting Rights Act, U.S. DEP'T OF JUSTICE, http://www.justice.gov/crt/ about/vot/misc/sec_4.php\#bailout_list (last visited Sep. 7, 2013). 
ensure that the right to vote is not denied based on race, ethnicity, or English literacy. ${ }^{89}$.

\section{States' Rights}

The states' rights opposition to section 5 is a poorly constructed Tenth Amendment challenge to perceived federal overreach. The states' rights argument, unfortunately, has been championed by several Supreme Court Justices, particularly those with strong beliefs in limiting the role of the federal government.90 In Shelby County, the majority characterized this as an "equal sovereignty" of the states doctrine. ${ }^{91}$ Much like Justice Kennedy's statements during oral argument in NAMUDNO, ${ }^{92}$ and numerous statements in Shelby County, the states' rights argument is misguided-it focuses on harm to the state, rather than on harm to individual voters. ${ }^{93}$ Some foes of section 5 contend that the difference between covered and noncovered jurisdictions lies in the federal government's usurpation of the state's right to govern. ${ }^{94}$ Federalism concerns are particularly linked to the section 5 preclearance requirement and are coupled with assertions that the federal government has usurped the rights of the states. ${ }^{95}$ Indeed, Supreme Court Justices have criticized the classification of states into

89 See NAMUDNO, 557 U.S. at 210-11 (broadening the definition of "political subdivision" under section 5 to expand eligibility for bailout).

90 See Corey J. Wasserburger, Note, If It's Not Broken, Then Why Fix It? The U.S. Supreme Court Signals a Shift Under Section 5 of the Voting Rights Act in Northwest Austin Municipal Utility District Number One v. Holder, 129 S. Ct. 2504 (2009), 89 NeB. L. REv. 420, 430-31 (2010) ("Arguably, the Voting Rights Act provides one of the most dramatic backdrops for the continuing evolution of federalism, as embodied in the current paradigm of 'New Federalism.' It is this paradigm, and its lack of deference to congressional findings, which will likely shape future challenges under the Voting Rights Act.").

91 See Shelby Cnty. v. Holder, 133 S. Ct. 2612, 2624 ("[D]espite the tradition of equal sovereignty, the Act applies to only nine States (and several additional counties).").

92 See supra note 16 and accompanying text.

93 See Charles M. Blow, Op-Ed., Vulnerability of the Vote, N.Y. Times (Feb. 27, 2013), http:/www.nytimes.com/2013/02/28/opinion/blow-vulnerability-of-the-vote.html (arguing that section 5 should be expanded because voters remain vulnerable to discriminatory practices).

94 See NAMUNDO, 557 U.S. at 217 (Thomas, J., dissenting) ("State autonomy with respect to the machinery of self-government defines the States as sovereign entities rather than mere provincial outposts subject to every dictate of a central governing authority.").

95 See, e.g., Kareem U. Crayton, Reinventing Voting Rights Preclearance, 44 IND. L. Rev. 201, 230-40 (2010) (suggesting a new framework that could address federalism concerns); Luis Fuentes-Rohwer, Understanding the Paradoxical Case of the Voting Rights Act, 36 FLA. Sr. U. L. REV. 697, 719 (2009) (arguing that federalism concerns are unfounded); Franita Tolson, Reinventing Sovereignty?: Federalism as a Constraint on the Voting Rights Act, 65 VAND. L. REV. $1195,1197,1259$ (2012) (arguing that the states and the federal government share power to govern elections). 
covered and noncovered jurisdictions. ${ }^{96}$ The concern that states are treated differently was noted in Katzenbach, which stated that "[i]t is irrelevant that the coverage formula excludes certain localities which do not employ voting tests and devices but for which there is evidence of voting discrimination by other means." 97 As discussed above, Congress sought to address voting discrimination "by other means" in its 2006 reauthorization. ${ }^{98}$

Scholars have argued that too much emphasis is placed on states' rights and not enough on the shared role of election administration between states and the federal government.99 Indeed, the right of Congress to intervene in the process of elections pursuant to its authority under the Fourteenth and Fifteenth Amendments is well-settled ${ }^{100}$ but unfortunately often ignored.

This bellow for state sovereignty is not new; these kinds of remarks echo a previous generation that believed firmly in the right of states to control election administration without federal intervention. ${ }^{101}$ One of the more famous proponents of the states' rights argument was former Alabama Governor George Wallace, ${ }^{102}$ who once

96 See, e.g., NAMUNDO, 557 U.S. at 212-29 (Thomas, J., dissenting).

97 Katzenbach, 383 U.S. at 330-31; see also Kousser, supra note 29, at 683-84 (explaining that Katzenbach depicted section 5 "as a wholesale bureaucratic intrusion by an all-powerful federal government on its federalist subordinates, the state and local governments").

98 See supra notes 66-72 and accompanying text (discussing 2006 amendments); infra Part III (discussing Congress's consideration of racially polarized voting).

99 See, e.g., Tolson, supra note 95, at 1201 ("But sovereignty, I argue, plays an important role in understanding the scope of congressional power to regulate state electoral mechanisms. Although Congress usually intervenes in state electoral practices pursuant to its enforcement power under the Fourteenth and Fifteenth Amendments, the Elections Clause serves as the baseline for the relationship between Congress and the states with respect to elections. And since the Elections Clause gives Congress final policymaking authority over federal elections and the Fourteenth and Fifteenth Amendments extend this authority to state elections, any judicially enforced federalism norm in favor of state power is illegitimate. These factors require the Court to employ rational basis review of the legislative record of the VRA for any challenges going forward.").

100 U.S. ConsT. amend. XIV, $\S 1$ ("No State shall ... deny to any person within its jurisdiction the equal protection of the laws."); U.S. Const. amend. XV ("The right of citizens of the United States to vote shall not be denied or abridged by the United States or by any State on account of race, color, or previous condition of servitude. The Congress shall have power to enforce this article by appropriate legislation.").

101 See Kousser, supra note 29, at 688 (citing Steven F. Lawson, BLACK Ballots: Voting RigHTS IN THE SOUTH, 1944-1969, at 319-30 (1976)) ("As for principle, the white southern arguments against Section 5 from the beginning had been that it was an antisouthern infringement on state's rights.").

102 George Wallace was a four-term governor of Alabama and became infamous for his first inaugural address touting segregation, as well as his 1963 "Stand in the School House Door" speech at the University of Alabama. Alabama Governors: George C. Wallace, Ala. Dep'T 
famously said, "I draw the line in the dust and toss the gauntlet before the feet of tyranny ... and I say, segregation now, segregation tomorrow, segregation forever." ${ }^{103} \mathrm{He}$ considered the intervention of the federal government in state matters such as voter registration an unwelcome invasion and used his opposition to federal intervention as an election strategy. ${ }^{104}$ A more recent example is Texas Governor Rick Perry, who has been a staunch states' rights advocate. ${ }^{105}$ Unfortunately, in covered jurisdictions, that old South states' rights argument has meant the passage of disenfranchising legislation that, but for section 5 , would inhibit the ability of minority citizens to participate in the election process. ${ }^{106}$

Additionally, jurisdictions maintain that compliance with section 5 imposes exorbitant costs. These costs, however, are de minimis when compared with the time and expense of litigation. ${ }^{107}$ Importantly, the costs imposed on eligible voters who are the victims of discriminatory legislation are immense. Denying one eligible citizen the right to register and vote because of ill-advised, unstudied, partisan legislation adds immeasurable costs to our democratic process.

ARCHIVEs \& HisT., http://www.archives.state.al.us/govs_list/g_wallac.html (last visited Sep. 7, 2013).

103 George C. Wallace, Governor of Ala., Inaugural Address 2 (Jan. 14, 1963), available at http://digital.archives.alabama.gov/cdm/singleitem/collection/voices/id/2952/rec/5.

104 Twenty years later in 1982, Wallace ran for governor of Alabama for a fourth time. During this campaign, he admitted that he had been wrong on the issue of race. In that election he was elected with a coalition of African Americans, organized labor unions, and advocates of public education. He won all ten of the state's majority black counties, some with a considerable margin. This election served as his last; he retired at the end of the term. But Wallace made noteworthy admissions: "We thought [segregation] was in the best interests of all concerned. We were mistaken," he told a black group in 1982. "'The Old South is gone,' but 'the New South is still opposed to government regulation of our lives." Richard Pearson, Former Ala. Gov. George C. Wallace Dies, WASH. Post, Sept. 14, 1988, at A1.

105 In his book, Fed Up! Our Fight to Save America from Washington, Rick Perry wrote, "From marriage to prayer, from zoning laws to tax policy, from our school systems to health care, and everything in between, it is essential to our liberty that we be allowed to live as we see fit through the democratic process at the local and state level." Rick Perry, Fed Up! Our Fight to SAVe AMERICA From Washington 27 (2010).

106 History details the need for oversight to avoid discrimination in voting. See supra Part I.

107 Pursuant to section 5 regulations, the Attorney General has sixty days to review a submission. 42 U.S.C. $\$ 1973 c$ (a) (2006). Compare this timeline to that of litigation, which can last six months or more, even with an expedited docket, and can have extreme costs. Moreover, should jurisdictions decide to submit changes to the federal district court, it will incur considerable litigation costs. 


\section{Two Steps Back: Voter ID}

An illustrative depiction of the modern day impact of section 5 can be found by comparing covered and noncovered jurisdictions and their plans for implementation of voter ID laws. While these laws existed well before the 2012 election, ${ }^{108}$ they received an enormous amount of attention in the media and the legislature after the 2010 election and throughout the 2012 election cycle. ${ }^{109}$ Since January 2011, at least 180 bills have been introduced in forty-one states. ${ }^{110}$ By October 2012, after considerable litigation and advocacy, sixteen new restrictive laws and two restrictive executive actions were adopted in thirteen states. ${ }^{111}$ Six states passed restrictive voter ID laws that required voters to present a specified form of identification, such as a driver's license or passport. ${ }^{112}$ Under the most restrictive legislation, the only acceptable form of identification was' a government-issued photo ID; student IDs, even if issued by a state-supported public institution, were not acceptable forms of identification. ${ }^{113}$ Importantly, legislatures continue to pass laws that change the requirements for voting and have a potentially adverse impact on minority voters. ${ }^{114}$

108 As a response to the 2000 presidential election debacle, many states began the task of "fixing" the election process. According to the National Conference of State Legislatures, "[s]ince 2001, nearly 1,000 bills have been introduced in a total of 46 states. Twenty-four states have passed major legislation during the period 2003-2012 (not including gubernatorial vetoes in five states in 2011)." Voter Identification Requirements, supra note 5.

109 See, e.g., Michael Cooper, New State Rules Raising Hurdles at Voting Booth, N.Y. Times, Oct. 3, 2011, at A1; Molly Ball, How State Legislatures Could Affect the 2012 Elections, Polrico (June 5, 2011, 7:03 AM), http://www.politico.com/news/stories/0611/56264.html; Ari Berman, Courts Block GOP Voter Suppression Laws, NATion (Oct. 2, 2012, 12:33 PM), http:// www.thenation.com/blog/170287/courts-block-gop-voter-suppression-laws; Danielle Lynch, More than 5 Percent of Chester County Voters Have No PennDOT ID, DaILy Loc. News (July 6, 2012, 4:03 PM), http://www.dailylocal.com/article/20120706/NEWS01/120709762/more-than-5-percentof-chester-county-voters-have-no-penndot-id; Nate Silver, Measuring the Effects of Voter Identification Laws, N.Y. Times FiveThirTyEight (July 15, 2012, 9:28 AM), http://fivethirtyeight .blogs.nytimes.com/2012/07/15/measuring-the-effects-of-voter-identification-laws/.

110 See WeISER \& KASDAN, supra note 8, at 1.

111 See Election 2012: Voting Laws Roundup, supra note 24.

112 In some states, a voter with ID can vouch for a voter without ID. Voter Identification Requirements, supra note 5 . Other states ask a voter without ID to provide personal information such as a birth date, or sign an affidavit swearing to his or her identity. Id.

113 See Mary Beth Schneider, Bill Would Restrict College Students' Vote, Indianapolis Star, Feb. 6, 2013, at B1 (discussing a bill that was introduced in the Indiana House of Representatives that would prevent students who pay out-of-state tuition from voting in Indiana); see also infra Part II.A.1 (discussing Texas voter ID legislation).

114 See, e.g., Chelyen Davis, House Passes Cole Bill to Limit Voter ID, Fredericksburg FrEe LANCE-STAR (Feb. 5, 2013, 12:15 PM), http://news.fredericksburg.com/on-politics/2013/02/ 05/house-passes-cole-bill-to-limit-voter-id/. The bill would remove utility bills, pay checks, bank 
Voting rights advocates feared that the restrictive changes would impact minority voters and in some instances preclude eligible persons from exercising the franchise in the same way that poll taxes and literacy tests did in the past. ${ }^{115}$ In response, lawsuits challenging these laws were filed, and in many instances courts determined that the risk of disenfranchisement far outweighed the state's reason for passing the law. ${ }^{116}$

While states have the authority to determine the parameters for voting, ${ }^{117}$ the federal government has the mandate to ensure that the process is not tainted with racial discrimination. ${ }^{118}$ Voter ID laws, in large part, have been found to disadvantage minorities, the elderly, and young people. ${ }^{119}$ After the passage of many of these laws, advocacy groups and the Department of Justice fought against their imple-

statements, and Social Security cards as acceptable forms of identification. Id. The bill would accept a concealed weapons permit. Id.

115 See, e.g., Shelley de Alth, ID at the Polls: Assessing the Impact of Recent State Voter ID Laws on Voter Turnout, 3 HARv. L. \& PoL'y Rev. 185, 202 (2009) (considering the myriad arguments surrounding voter ID); Schultz, supra note 26, at 485 (comparing voter ID to poll tax); Debbie Hines, Op-Ed., Voter ID Laws Are the New Poll Tax and Literacy Tests, HuFFINGTON Post (Aug. 20, 2012, 4:26 PM), http://www.huffingtonpost.com/debbie-hines/voter-idis-the-new-poll-tax_b_1797394.html (describing voter ID laws as the new barriers to the ballot).

116 See South Carolina v. United States, 898 F. Supp. 2d 30, 32 (D.D.C. 2012) (finding no discriminatory purpose in voter ID law, but delaying implementation to avoid discriminatory effects in 2012 election); Texas v. Holder, 888 F. Supp. 2d 113, 114-15 (D.D.C. 2012) (finding proposed voter ID law likely to have a retrogressive effect); Applewhite v. Pennsylvania, No. 330 M.D.2012, 2012 WL 4497211, at *1 (Pa. Commw. Ct. Oct. 2, 2012) (ordering preliminary injunction based on risk of voter disenfranchisement). But see Ind. Democratic Party v. Rokita, 458 F. Supp. 2d 775, 784 (S.D. Ind. 2006) (finding voter ID law reasonable restriction on time, place, and manner of voting), aff'd sub nom. Crawford v. Marion Cnty. Election Bd., 472 F.3d 949 (7th Cir. 2007), aff'd, 553 U.S. 181 (2008); Democratic Party of Ga., Inc. v. Perdue, 707 S.E.2d 67, 69 (Ga. 2011) (finding voter ID law reasonable regulation); League of Women Voters of Ind., Inc. v. Rokita, 929 N.E.2d 758, 760 (Ind. 2010) (denying facial challenge to voter ID law, but stating willingness to address future as-applied challenges); League of Women Voters Minn. v. Ritchie, 819 N.W.2d 636, 640 (Minn. 2012) (denying request to remove voter ID measure from ballot, but not reaching the merits of voter ID law itself).

117 U.S. ConsT. art. I, § 4, cl. 1 ("The Times, Places and Manner of holding Elections for Senators and Representatives, shall be prescribed in each State by the Legislature thereof; but the Congress may at any time by Law make or alter such Regulations, except as to the Places of [choosing] Senators."). Congress has the power to regulate the elections of representatives and senators. See, e.g., United States v. Gradwell, 243 U.S. 476, 482 (1917); Ex parte Siebold, 100 U.S. 371, 383-84 (1879); United States v. Manning, 215 F. Supp. 272, 286-87 (W.D. La. 1963).

118 The Constitution also gives the federal government authority over the electoral process. Power over federal election procedures is ultimately "committed to the exclusive control of Congress." Colegrove v. Green, 328 U.S. 549, 554 (1946); Ex parte Siebold, 100 U.S. at 384 ("When exercised, the action of Congress, so far as it extends and conflicts with the regulations of the State, necessarily supersedes them."); see also Foster v. Love, 522 U.S. 67, 69 (1997).

119 See GASKINS \& IYER, supra note 25. 
mentation. ${ }^{120}$ A comparison between the implementation processes for two voter ID laws provides an illustrative framework for assessing the continuing need for remedial legislation.

\section{A. A Tale of Two States}

\section{Covered Jurisdiction: Texas}

In 2011, Texas passed a new voter ID law. Under the old law, citizens needed to present a voter registration certificate in order to vote; other acceptable forms of identification included a driver's license, current utility bill, or bank statement. ${ }^{121}$ The new bill specified only six acceptable forms of identification, ${ }^{122}$ all of which were government-issued photo IDs that were harder for poor persons and minorities to obtain. ${ }^{123}$

Prior to its passage, the Texas legislature defeated several amendments that might have allowed the law to withstand legal scrutiny. ${ }^{124}$ Ignoring warnings that the bill, as written, would disenfranchise minorities and the poor, the legislature tabled or defeated amendments that would have, among other things, waived all fees for indigent persons who needed the underlying documents to obtain an "election identification certificate" ("EIC"), reimbursed impoverished Texans for EIC-related travel costs, permitted the use of student IDs and Medicare cards for identification, required Department of Public Safety offices to remain open in the evening and on weekends, and allowed indigent persons to cast provisional ballots without a photo ID. ${ }^{125}$

Because Texas was a covered jurisdiction under section 5 of the VRA, it sought preclearance from the United States Department of Justice prior to implementation and was denied in March 2012.126 The

120 See, e.g., Arizona v. Holder, 839 F. Supp. 2d 36 (D.D.C. 2012); Texas v. Holder, 888 F. Supp. 2d 113 (D.D.C. 2012), vacated and remanded, 133 S. Ct. 2886 (2013); Florida v. United States, 820 F. Supp. 2d 85 (D.D.C. 2011); Georgia v. Holder, 748 F. Supp. $2 d 16$ (D.D.C. 2010).

121 See Act effective Jan. 1, 2004, ch. 1315, § 27, 2003 Tex. Gen. Laws 4825.

122 Under the new legislation, the only acceptable forms of voter identification are a driver's license, election identification certificate, Department of Public Safety personal ID card, United States military ID, United States citizenship certificate, United States passport, and license to carry a concealed handgun issued by the Department of Public Safety. Tex. Elec. CODE ANN. § 63.0101 (West 2011).

123 See Texas v. Holder, 888 F. Supp. 2d at 144 (finding that the new restrictions would "impose strict, unforgiving burdens on the poor, and racial minorities in Texas [who] are disproportionately likely to live in poverty").

124 See id.

$125 \mathrm{Id}$.

126 Id. at 117. 
Department of Justice declined to preclear the law after finding that Texas did not meet its burden of demonstrating that the law would not place minority voters in a worse position. ${ }^{127}$ In response, Texas asked the United States District Court for the District of Columbia to reconsider its preclearance submission. ${ }^{128}$

In Texas v. Holder, the State of Texas sought a declaratory judgment stating that its newly enacted voter ID law merited section 5 preclearance. ${ }^{129}$ Texas alternatively requested that the district court declare section 5 unconstitutional. ${ }^{130}$ The United States argued that Texas's voter ID law would impose significant burdens on minority and student voters. ${ }^{131}$ The court found that Texas's voter ID law was the most stringent in the country, that it would almost certainly have a retrogressive effect, that it imposed strict and unforgiving burdens on the poor, and that racial minorities in Texas were disproportionately more likely to live in poverty. ${ }^{132}$ The District Court also denied preclearance. ${ }^{133}$ Accordingly, the state of Texas was not allowed to implement its restrictive voter ID law in the 2012 presidential election. ${ }^{134}$

Texas's passage of the voter ID law demonstrates an inflexible and tenacious approach to pursuing disenfranchising voter legislation. In the face of arguments that the legislation could adversely affect minorities and students, the state of Texas seemed determined to implement the legislation. The state's approach had a less drastic impact because the Attorney General and the courts blocked implementation using their section 5 authority, finding that the new legislation unjustly discriminated against minority voters and would place them in a worse position with respect to their ability to vote. ${ }^{135}$ While the Texas voter ID law did not withstand scrutiny, ${ }^{136}$ the lack of preclearance in non-

\footnotetext{
127 Id.

128 Id. at 114.

129 Id.

130 Id. at $118,123$.

131 Id. at 121 ("Moreover, the United States and Defendant-Intervenors argue that SB 14 will have a discriminatory effect-that is, it will 'lead to a retrogression in the position of racial minorities with respect to their effective exercise of the electoral franchise." (quoting Beer v. United States, 425 U.S. 130, 141 (1976))).

$132 I d$. at 141 ("Simply put, many Hispanics and African Americans who voted in the last election will, because of the burdens imposed by SB 14, likely be unable to vote in the next election. This is retrogression.").

133 Id, at 114.

134 See Charles Savage \& Manny Fernandez, Court Points to Discrimination in Halting Texas Voter ID Law, N.Y Times, Aug. 31, 2012, at A11.

135 Texas v. Holder, 888 F. Supp. 2d at 138.

136 Within hours of the Supreme Court's decision in Shelby County. v. Holder, $133 \mathrm{~S}$. Ct.
} 
covered states like Pennsylvania left voters vulnerable to similarly restrictive laws.

\section{Noncovered Jurisdiction: Pennsylvania}

The Commonwealth of Pennsylvania entered into the voter ID fray on March 7, 2012, when the Pennsylvania Senate approved a new photo ID law that was later approved by the Pennsylvania House of Representatives. ${ }^{137}$ Governor Tom Corbett signed Act 18 into law the same day that the House of Representatives approved it. ${ }^{138}$ Prior to the passage of Act 18, only first-time voters were required to provide an ID. 139 All that other voters needed to provide was a signature that election officials could verify to prevent voter fraud. ${ }^{140}$ Act 18 , however, required all persons wishing to vote to provide a governmentissued photo ID, and excluded many student IDs from the list of acceptable forms of identification. ${ }^{141}$ Although some exceptions existed, it did not provide for citizens to obtain the required forms of identification or allow persons without ID to vote on a regular ballot. ${ }^{142}$ Like Texas and other states, the Commonwealth stated that its primary reason for passing the bill was to prevent voter fraud and that it was optimistic that eligible voters could obtain the necessary documents to obtain an ID. ${ }^{143}$ While voter fraud was the stated motivation for the law, some party officials boasted that the voter ID law would provide an edge for the Republican Party in the presidential election. ${ }^{144} \mathrm{Be}-$

594 (2012), the state of Texas announced its intention to implement the legislation that the lower federal court previously found intentionally discriminatory against Latino and African American citizens. See Press Release, John Steen, Tex. Sec'y of State, Photo ID Now Required for Voting in Texas (June 25, 2013), http:/www.sos.state.tx.us/about/newsreleases/2013/062513.shtml.

1372012 Pa. Legis. Serv. 2012-18 (West).

138 Tony Romeo, Governor Corbett Signs Controversial Voter ID Bill into Law, CBS Philly (Mar. 15, 2012, 6:53 AM), http://philadelphia.cbslocal.com/2012/03/15/governor-corbettsigns-controversial-voter-id-bill-into-law/.

13925 Pa. Stat. ANN. $\$ 3050$ (West 2003) (effective to October 7, 2004) (amended 2012). 140 Id.

141 Id. Pennsylvania's Act 18 required that the identification include the name of the individual and substantially conform to the individual's name on the precinct register. Id. $\S 2602(\mathrm{z} .5)$. It also required that it contain a photograph and expiration date, and be government-issued. $I d$.

$142 I d . \$ 3050$. The provisional ballot exception may be invoked by individuals who otherwise were unable to obtain ID on Election Day. Id. In order for the provisional ballot to be counted, within six calendar days of the election the individual must appear in person at the county board of elections to complete the affirmation and present proof of identification or submit an electronic or paper copy of the affirmation and the proof of identification. Id.

143 Press Release, Tom Corbett, Gov. of Pa., Governor Corbett Signs Voter ID Bill to Require Photo Identification (Mar. 14, 2012).

144 Kelly Cernetich, Turzai: Voter ID Law Means Romney Can Win PA, PoliticsPA (June 
cause Pennsylvania was not subject to the section 5 preclearance requirement, its implementation of the new voter ID law was chaotic. After passage of the law and the announcement that it would be in effect for the April 2012 presidential primary, as well as the general election in November, Pennsylvania realized that it had a number of changes to implement. ${ }^{145}$ These changes caused massive confusion and began to undermine citizen trust in the democratic process. ${ }^{146}$

Initially, the Pennsylvania Department of State estimated that approximately one percent of voters, 80,000 Pennsylvanians, did not have proper ID. ${ }^{147}$ On July 3, 2012, however, the Department of State reported that nine percent of registered voters, 759,000 Pennsylvanians, did not have appropriate identification. ${ }^{148}$ Additionally, there were nearly 600,000 additional Pennsylvanians with expired IDs, raising the total number of individuals without proper identification to nearly 1.5 million. ${ }^{149}$

Shortly after passage of the law, a group of citizens filed suit challenging it. The plaintiffs in Applewhite v. Commonwealth ${ }^{150}$ sought a preliminary injunction against enforcement of the law and highlighted

25, 2012, 12:53 PM), http://www.politicspa.com/turzai-voter-id-law-means-romney-can-win-pa/ 37153/ (noting that at a Pennsylvania Republican Committee meeting, House Majority Leader Mike Turzai stated: "Pro-Second Amendment? The Castle Doctrine, it's done. First pro-life legislation-abortion facility regulations-in 22 years, done. Voter ID, which is gonna allow Governor Romney to win the state of Pennsylvania, done.").

145 In early implementation of the photo ID law, Pennsylvania adopted several new standards for obtaining ID and created a new form of identification. The Commonwealth also introduced the creation of a new card that can be issued to voters who need photo identification under Pennsylvania's voter ID law. The new voter identification card would be available to registered voters who are not able to provide all of the documents they would normally need to obtain a photo ID from the Pennsylvania Department of Transportation, such as a birth certificate. Obtaining a Free ID for Voting Purposes, PA. DeP'T OF TransP., http://www.dmv.state.pa .us/voter/voteridlaw.shtml (last visited Sep. 7, 2013).

146 Deborah Charles, Complaints About Voter IDs, Long Lines in U.S. Election, ReUTERS (Nov. 7, 2012, 2:42 PM), http://www.reuters.com/article/2012/11/07/usa-campaign-voting-idUSL1 E8M6DUF20121107.

147 See Senate Appropriations Committee Fiscal Note, 2011 Legis. Bill Hist. PA H.B. 934 (Pa. 2012) (indicating that the Pennsylvania Department of Transportation estimated that "about $.929 \%$ of registered voters in the state do not have a PennDOT ID card").

148 Dennis Owens, Outreach and Outrage Continue over Voter ID Law, АВC27.сом (July 19, 2012, 9:11 PM), http://www.abc27.com/story/19058756/outreach-and-outrage-continue-overvoter-id-law.

149 Lauri Lebo, Voter ID Trial Day 4: State Really Has No Idea How Many Are Without Valid Voter ID, SPEAKING FreELY (July 30, 2012, 8:47 PM), http://aclupa.blogspot.com/2012/07/ voter-id-trial-day-4-state-really-has.html.

150 Applewhite v. Commonwealth, No. 330 M.D.2012, 2012 WL 4497211 (Pa. Commw. Ct. Oct. 2, 2012). 
many issues regarding the disparate impact on minority citizens. ${ }^{151}$ After a months-long battle that culminated in an appeal to the Pennsylvania Supreme Court, ${ }^{152}$ the trial court ultimately agreed on remand that the law would adversely affect eligible citizens and entered an injunction against the use of the voter ID law for the November 2012 election. ${ }^{153}$

Notwithstanding the court's ruling, many reports surfaced that election officials continued to advise citizens that an ID was required to vote in the November general election when it in fact was not, ${ }^{154}$ or told them that they were at the wrong precinct and could not vote. ${ }^{155}$ Election officials succeeded in confusing voters. ${ }^{156}$ In addition to misinformation from election officials on Election Day, some political organizations specifically targeted African American and other minority precincts. ${ }^{157}$

The voter ID saga in Pennsylvania is a portrait of what can indeed happen if section 5 of the VRA is eliminated. While proponents argue that without section 5 , litigation under section 2 of the VRA

151 Id. (referencing other issues of outreach and education, voter disenfranchisement, and liberal access).

152 Applewhite v. Commonwealth, 54 A.3d 1, 2 (Pa. 2012).

153 Applewhite, 2012 WL 4497211, at*3 "I am not still convinced in my predictive judgment that there will be no voter disenfranchisement arising out of the Commonwealth's implementation of a voter identification requirement for purposes of the upcoming election. Under these circumstances, I am obliged to enter a preliminary injunction.").

154 See, e.g., Jessica Parks, Pennsylvania's New Voter ID Law Causes Confusion, Voters Say, Philly.com (Nov. 7, 2012), http://articles.philly.com/2012-11-07/news/34974527_1_voter-id-lawpoll-workers-general-election.

155 See, e.g., A Voter Protection Experience, BLS ADVOCATE, http://blsadvocate.org/tag/ provisional-ballots/ (last visited Sep. 7, 2013) ("[Other voters] were given inaccurate information, like the wrong poll site. One particularly frustrating case was a black man who waited on line to vote and was then told that he was at the wrong poll site and to go to a different location to vote. When he relayed this information to me, I asked if they called the Board of Elections to determine his correct polling location. He told me that the poll worker did not call any one, but simply asked him his address and upon hearing his address told him that this was not the correct poll site for him. It turned out that the poll worker was wrong, and that this was the man's correct poll site. I told the voter to go back inside and speak to the poll worker and tell him that this was his correct poll site. The man was again turned away, and I had to pull up the Pennsylvania Board of Elections' website on my phone, which showed that this was the man's polling location before the man's name was found in the poll book and he was able to vote.").

156 Samantha Stainburn, Pennsylvania's Voter ID Law Causes Confusion, GlobalPost (Nov. 6, 2012, 6:26 PM), http:/www.globalpost.com/dispatch/news/regions/americas/unitedstates/121106/pennsylvania-voter-id-law-causes-confusion (noting that "Pennsylvania's new voter ID law is confusing voters in the state today ....").

157 See Meteor Blades, The Latest on Voting Shenanigans in Oregon, Pennsylvania and Arizona, DAILy Kos (Nov. 5, 2012, 10:36 AM), http://www.dailykos.com/story/2012/11/05/1155976/The-latest-on-voting-shenanigans-in-Oregon-Pennsylvania-and-Arizona\#. 
could provide a result similar to that in Texas, it is the lack of preemption that makes the difference in these two states. With a preemptive component stronger than a preliminary injunction, Pennsylvania could have avoided confusing its citizens with various iterations of implementation. Indeed, the injunction against the voter ID law created further confusion because it suggested that poll workers may request ID but were not required to do so. ${ }^{158}$ Accordingly, while no ID was required, allowing poll workers to request ID provided room for discriminatory execution, where some citizens are asked for ID and others are not.

Pennsylvania is not a VRA-covered jurisdiction, nor should it be. It does not have the same history of official discrimination as the currently covered jurisdictions. Texas and Pennsylvania demonstrate the need for preemptive legislation in measures affecting voting. Even if a jurisdiction is not subject to section 5 coverage, a universal standard for laws affecting voting can lessen the passage of discriminatory laws.

\section{Solutions That Fit the Problem}

While many argue that the VRA has run its course and is no longer needed, it is important to note that Congress employed a studied approach to address systemic racial discrimination and developed legislation that aided in providing widespread access to the voting booth. While some opponents of the Act view it as "outdated," 159 the prophylactic role that section 5 plays today is still crucial. When Congress considers amending the VRA, it should incorporate the following: (1) the history of official discrimination in each state; (2) the extent of racially polarized voting in a jurisdiction; and (3) the power of a preemptive component. ${ }^{160}$

158 See Applewhite, 2012 WL 4497211, at *1.

159 See, e.g., Brief of Amicus Curiae Cato Institute Supporting Petitioner at 20, Shelby Cnty. v. Holder, 133 S. Ct. 2612 (2013) (No. 12-96), 2013 WL 75423 ("The VRA's outdated provisions no longer advance the Fifteenth Amendment's simple bar on race-based disenfranchisement.").

160 Section 2 of the VRA lists a history of official discrimination in voting and a history of official discrimination in education, employment, and housing as two of the eight Senate Factors that courts should consider in determining whether voting discrimination is present. The factors include:

[T] he history of voting-related discrimination in the State or political subdivision; the extent to which voting in the elections of the State or political subdivision is racially polarized; the extent to which the State or political subdivision has used voting practices or procedures that tend to enhance the opportunity for discrimination against the minority group, such as unusually large election districts, majority vote requirements, and prohibitions against bullet voting; the exclusion of members of the minority group from candidate slating processes; the extent to which minor- 


\section{A. History of Official Discrimination}

A very important difference between a covered jurisdiction, like Texas, and a noncovered jurisdiction, like Pennsylvania, is the history of official discrimination, particularly in the area of voting. ${ }^{161}$ The state of Texas has an extremely long and well-documented history of discrimination in voting. ${ }^{162}$ The record of discrimination includes historic as well as recent discrimination. ${ }^{163}$

In 2012, the United States District Court for the District of Columbia found that the Texas redistricting plan had intentionally discriminated against minorities. ${ }^{164}$ Also in 2012, the court found that Texas's voter ID bill was not entitled to preclearance because the state failed to meet its burden of demonstrating that the proposed voter ID

ity group members bear the effects of past discrimination in areas such as education, employment, and health, which hinder their ability to participate effectively in the political process; the use of overt or subtle racial appeals in political campaigns; and the extent to which members of the minority group have been elected to public office in the jurisdiction.

Thornburg v. Gingles, 478 U.S. 30, 44-45 (1986).

161 The Leadership Conference on Civil and Human Rights consists of a coalition of approximately 200 organizations dedicated to the preservation of human and civil rights. Prior to the 2006 reauthorization of the VRA, the Leadership Conference established RenewtheVRA .org and commissioned individuals to write a report for each of the section 5 jurisdictions detailing the history of voter discrimination from 1982-2006. The reports can be found at: http://www .civilrights.org/voting-rights/vra/states.html.

162 For approximately two decades from 1923 to 1944 , the state of Texas repeatedly attempted to limit the ability to vote in Democratic primaries to whites, excluding African Americans and Mexican Americans. See generally Grovey v. Townsend, 295 U.S. 45 (1935); Nixon v. Condon, 286 U.S. 73 (1932); Nixon v. Herndon, 273 U.S. 536 (1927). The Supreme Court invalidated a resolution by the Texas Democratic Party limiting party membership to white citizens in Smith v. Allwright, 321 U.S. 649 (1944), and struck down the all-white primary for good in 1953 in Terry v. Adams, 345 U.S. 461 (1953). Texas continued to implement and enforce discriminatory practices and methods, however, such as the poll tax and requiring annual registration. Nina Perales, Luis Figueroa \& Criselda G. Rivas, RenewtheVRA.org, Voting Rights IN TEXAs 1982-2006, at 9 (2006), available at http://www.maldef.org/resources/publications/Texas VRA.pdf.

163 See, e.g., Perales et Al., supra note 162, at 11-13.

164 Texas v. United States, 887 F. Supp. 2d 133, 166 (D.D.C. 2012) ("We find it telling that the legislature deviated from typical redistricting procedures and excluded minority voices from the process even as minority senators protested that section 5 was being run roughshod."); see also Manny Fernandez, Federal Court Finds Texas Voting Maps Discriminatory, N.Y. TIMES, Aug. 29, 2012, at A13; O. Ricardo Pimentel, Voter Discrimination Deep in Heart of Texas, SAN ANTONio Express-News (May 24, 2012, 11:18 PM), http:/www.mysanantonio.com/news/ news_columnists/o_ricardo_pimentel/article/Voter-discrimination-deep-in-heart-of-Texas-35845 53.php\#ixzz2K5yM3cSq ("This is not ancient history. And I'd submit that voter ID also is part of these 'second generation' efforts. It is a solution in search of a problem. Its real aim is to thwart voters, many of them minorities, who happen to vote Democrat. . . The answer is clear from this opinion. The focus should remain because the desire to discriminate still lies disproportionately and too deep in the heart of 'covered jurisdictions,' Texas among them."). 
bill was not retrogressive, and that the impact would fall on poor minority voters. ${ }^{165}$ Proponents of section 5 declared the ruling a clear victory. ${ }^{166}$

Another example of Texas's approach to voting rights can be found in the 2006 Texas redistricting case League of United Latin American Citizens v. Perry, ${ }^{167}$ where the Supreme Court noted the following:

The District Court recognized the long history of discrimination against Latinos and Blacks in Texas, and other courts have elaborated on this history with respect to electoral processes:

Texas has a long, well-documented history of discrimination that has touched upon the rights of African-Americans and Hispanics to register, to vote, or to participate otherwise in the electoral process. Devices such as the poll tax, an all-white primary system, and restrictive voter registration time periods are an unfortunate part of this State's minority voting rights history. The history of official discrimination in the Texas election processstretching back to Reconstruction-led to the inclusion of the State as a covered jurisdiction under Section 5 in the 1975 amendments to the Voting Rights Act. Since Texas became a covered jurisdiction, the Department of Justice has frequently interposed objections against the State and its subdivisions.

In addition, the political, social, and economic legacy of past discrimination for Latinos in Texas may well hinder their ability to participate effectively in the political process. ${ }^{168}$

Similarly, addressing the preclearance provisions and the state of Texas, the Mexican American Legal Defense Fund argued in its amicus brief in the NAMUDNO case that Texas has had more than its fair

165 Texas v. Holder, 888 F. Supp. 2d 113, 138 (D.D.C. 2012) ("Because all of Texas's evidence on retrogression is some combination of invalid, irrelevant, and unreliable, we have little trouble concluding that Texas has failed to carry its burden."). Moreover, the court found actual harm to minority voters. Id. at 141 .

166 Robert Barnes, Federal Court Throws Out Texas Redistricting Plan, Citing Bias, WasH. Post, Aug. 29, 2012, at A5 (quoting Lone Star Project Director Matt Angle as stating, “'The court's decision is a damning indictment of [Governor] Rick Perry and other Texas Republican leaders who, in a cynical attempt to hold on to power, engaged in intentional discrimination against Texas Latino and African-American voters.' ").

167 League of United Latin Am. Citizens v. Perry, 548 U.S. 399 (2006).

168 Id. at $439-40$ (citations omitted). 
share of section 5 objections evidencing the high level of discriminatory practices affecting the right to vote. ${ }^{169}$

Additionally, covered jurisdictions like Texas have faced numerous cases alleging violations of section 2 of the VRA, which prohibits voting practices or procedures that discriminate against racial, ethnic, or language minorities. ${ }^{170}$ The plethora of judicial findings concerning covered jurisdictions has stark similarities to the purposeful discrimination against minorities conducted in the mid-twentieth century. ${ }^{171}$ Accordingly, Texas's past and recent history of official intentional discrimination make clear the persistent need for federal oversight to protect minority citizens from this significant evil.

\section{B. Racially Polarized Voting}

In renewing the VRA, Congress noted the existence of racially polarized voting in the covered jurisdictions as an indication that section 5 had not yet finished the business of eliminating voting discrimination. ${ }^{172}$ In the 2006 reauthorization, Congress considered the extent to which racially polarized voting existed in covered jurisdictions in determining whether to extend section $5 .{ }^{173}$ In Shelby County, the dis-

169 Brief for Intervenors-Appellees at 15, Nw. Austin Mun. Util. Dist. No. One v. Holder (NAMUDNO), 557 U.S. 193 (2009) (No. 08-322) ("Between the 1982 reauthorization and 2004, [the Department of Justice] interposed 105 objections to discriminatory voting changes in Texas-ten of which were statewide. At the local level, Section 5 objections prevented the implementation of discriminatory electoral changes in 72 Texas counties where over two-thirds of the State's minority population resides. Twenty-eight counties, utilizing various strategies to obstruct minority participation, have drawn multiple Section 5 objections in this period. Furthermore, an additional 60 submissions from Texas jurisdictions were either withdrawn in response to [a Department of Justice request for more information about a proposed voting change] or denied judicial preclearance, and Texas plaintiffs also brought 29 successful Section 5 enforcement actions." (citations omitted)).

170 Id. ("[B]etween 1982 and 2004, more than 150 Section 2 suits were resolved on behalf of minority voters in Texas, leading 142 jurisdictions to alter discriminatory voting practices."); see also Ellen Katz et al., Documenting Discrimination in Voting: Judicial Findings Under Section 2 of the Voting Rights Act Since 1982, 39 U. Mich. J.L. Reform 643, 655 n.41 (2006).

171 See Voting Rights Act: The Continuing Need for Section 5: Hearing Before the Subcomm. on the Constitution of the H. Comm. on the Judiciary, 109th Cong. 4 (2005) (statement of Laughlin McDonald, Dir., ACLU Voting Rights Project) ("I have been struck with the fact that invariably someone will say we don't need section 5 anymore because Bull Connor is dead."); Kousser, supra note 29 , at 773-74 ("It would lessen any opprobrium attached to coverage by showing that the adoption and employment of discriminatory devices has taken place in areas and at times in which invidious expressions of discrimination are rare, that such discrimination is more a matter of power than of prejudice-that Bull Connor may be dead, but Tom DeLay is not." (footnotes omitted)).

172 See supra Part I.B.

173 " $[\mathrm{R}]$ acial polarization exists where there is a consistent relationship between [the] race of the voter and the way in which the voter votes, or to put it differently, where black voters and 
trict court described substantial evidence of continued voter discrimination that Congress relied upon to justify the 2006 reauthorization of the VRA. ${ }^{174}$ The district court in Shelby County also recognized the magnitude of racially polarized voting, particularly in covered jurisdictions, as an indicator of ongoing discrimination. ${ }^{175}$

According to highly regarded political scientists who have served as experts in voting rights cases, "there is a link between racially polarized voting and discriminatory exclusion of minority voters from the democratic process. Specifically, racially polarized voting makes certain discriminatory voting practices, such as vote dilution, increasingly possible." 176 In this new millennium, courts continue to find the presence of racially polarized voting, overwhelmingly in section 5 covered jurisdictions. ${ }^{177}$ In an amicus brief for the respondents in Shelby County, a group of political science and law professors reveal important considerations:

Racially polarized voting in many covered jurisdictions continues to be extreme. In addition to the racially polarized voting in covered jurisdictions in the past three presidential elections, post-reauthorization data also reveal extraordinary polarization in other statewide contests. For instance, in post-reauthorization United States Senate contests in Mississippi, the White crossover vote for the Black-preferred candidate has averaged only $13 \%$. In the 2011 gubernatorial race in Mississippi, the Black candidate, Mayor Johnny L. DuPree, received a share of the total vote $(39.02 \%)$ that was almost identical to the Black population of the state (37.3\%). Further analysis indicates that DuPree won an estimated $20 \%$ of the White vote, but more than $80 \%$ of the Black vote. No Black political candidate has been elected statewide in Mississippi since Reconstruction. ${ }^{178}$

white voters vote differently." Thornburg v. Gingles, 478 U.S. 30, 53 n.21 (1986) (internal quotation marks and citation omitted). In other words, "[r]acially polarized voting occurs when voting blocs within the minority and white communities cast ballots along racial lines." H.R. REP. No. 109-478, at 34 (2006).

174 Shelby Cnty. v. Holder, 811 F. Supp. 2d 424, $463-92$ (D.D.C. 2011).

175 Id. at 487.

176 Brief for Professors Richard L. Engstrom et al. as Amici Curiae Supporting Respondents at 4-5, Shelby Cnty. v. Holder, 133 S. Ct. 2612 (2013) (No. 12-96).

177 See, e.g., League of United Latin Am. Citizens v. Perry, 548 U.S. 399, 427 (2006); Bone Shirt v. Hazeltine, 461 F.3d 1011, 1020-21 (8th Cir. 2006) (involving legislative redistricting); Jamison v. Tupelo, 471 F. Supp. 2d 706, 713 (N.D. Miss. 2007).

178 Brief of Political Science and Law Professors as Amici Curiae Supporting Respondents at 19-21, Shelby Cnty. v. Holder, 133 S. Ct. 2612 (2013) (No. 12-96) (footnotes and citation omitted). 
The contemporary instances of racially polarized voting, particularly its prevalence in covered jurisdictions, evinces the rationale for remedial legislation and a continuing need to address concentrated voting discrimination. ${ }^{179}$ Indeed, political scientists have found that a real difference in levels of racially polarized voting exists between covered and noncovered jurisdictions and that covered jurisdictions are becoming more racially polarized, not less. ${ }^{180}$ The continued and increasing incidence of racially polarized voting and Congress's recognition of this problem in the 2006 reauthorization of the VRA provides further support for continued federal oversight of state voting procedures. ${ }^{181}$

\section{Preemption Protection}

Preemption is a powerful tool in mitigating discriminatory legislation affecting voting. The preclearance doctrine in section 5 requires covered jurisdictions to submit voting changes for approval before they are allowed to put them into operation. ${ }^{182}$ The voting change is

179 See Crayton, supra note 10, at 975 ("[Racially polarized voting ("RPV")] analysis can ... direct the application of the special remedies contained in the preclearance regime of the VRA... This extra-litigative application of RPV data can offer an important measure of social progress toward the Fifteenth Amendment's guarantee of the equal enjoyment of the electoral franchise regardless of race. These studies, taken together, can help shed light on whether the special remedies in section 5 remain necessary in covered states and localities.").

180 See Stephen Ansolabehere, Nathaniel Persily \& Charles Stewart III, Race, Region, and Vote Choice in the 2008 Election: Implications for the Future of the Voting Rights Act, 123 HARV. L. Rev. 1385, 1425 (2010); Stephen Ansolabehere, Nathaniel Persily \& Charles Stewart III, Regional Differences in Racial Polarization in the 2012 Presidential Election: Implications for the Constitutionality of Section 5 of the Voting Rights Act, 126 HARv. L. REv. F. 205, 220 (2013), http://www.harvardlawreview.org/media/pdf/forvol126_persily.pdf ("There can be no doubt that the covered jurisdictions differ, as a group, from the noncovered jurisdictions in their rates of racially polarized voting. There can also be no doubt that voting in the covered jurisdictions as a whole is becoming more, not less, polarized over time.").

181 See South Carolina v. Katzenbach, 383 U.S. 301, 330 (1966) ("In identifying past evils, Congress obviously may avail itself of information from any probative source."); Laughlin McDonald, $A$ Challenge to the Constitutionality of Section 5 of the Voting Rights Act: Northwest Austin Municipal Utility District Number One v. Mukasey, 3 Charleston L. Rev. 231, 261-62 (2009) ("There is no question that Obama's election reflects an enormous advancement in race relations in the United States. . . But an examination of the election results shows that voting, particularly in the southern states covered by Section 5 , remains significantly polarized along racial lines.").

18228 C.F.R. $\S 51.1$ (a) (2012) provides in pertinent part:

Section 5 of the Voting Rights Act of 1965 ... prohibits the enforcement in any jurisdiction covered by section 4(b) of the Act ... of any voting qualification or prerequisite to voting, or standard, practice, or procedure with respect to voting different from that in force or effect on the date used to determine coverage, until either: 
reviewed to ensure that it does not have a discriminatory purpose or effect. ${ }^{183}$ A proposed plan is retrogressive under section 5 if its net effect reduces minority voters' "effective exercise of the electoral franchise" when compared to the benchmark plan. ${ }^{184}$ Section 5 of the VRA is a prime example of the Supremacy Clause's ability to preempt state law when it conflicts with federal law. ${ }^{185}$ Under section 5, whether a proposed law would place voters in a worse position is an evaluation that must occur prior to implementation. This requirement is also regarded as a powerful deterrent to blatantly discriminatory changes. ${ }^{186}$

Pennsylvania illustrates the pitfalls of a lack of preventive measures-particularly the stops and starts in implementation, the ability to implement a law without a reasoned approach or evaluative records, the confusion that results, protracted litigation and its costs, the harm to voter confidence, and the impact on voters of color, the

(1) A declaratory judgment is obtained from the U.S. District Court for the District of Columbia that [the change is permissible], or

(2) It has been submitted to the Attorney General and the Attorney General has [not objected].

183 The Department of Justice's Guidance Concerning Redistricting Under Section 5 of the Voting Rights Act states that

there are two necessary components to the analysis of whether a proposed redistricting plan meets the Section 5 standard. The first is a determination that the jurisdiction has met its burden of establishing that the plan was adopted free of any discriminatory purpose. The second is a determination that the jurisdiction has met its burden of establishing that the proposed plan will not have a retrogressive effect.

Guidance Concerning Redistricting Under Section 5 of the Voting Rights Act, 76 Fed. Reg. 7470 (Feb. 9, 2011).

184 Beer v. United States, 425 U.S. 130, 141 (1976).

185 Gilda R. Daniels, Senator Edward Kennedy: A Lion for Voting Rights, 14 N.Y.U. J. LegIS. \& PUB. PoL'Y 415, 424 (2011) ("Section 5 of the VRA also addresses discrimination, but attempts to do so preemptively."); Robert Bryson Carter, Note, Mere Voting: Presley v. Etowah County Commission and the Voting Rights Act of 1965, 71 N.C. L. Rev. 569, 573 (1993) ("This 'uncommon exercise' of federal power over substantive state law has proved to be the cornerstone of the Act's remarkable success because it removed what had been the insurmountable barrier of bringing a separate suit against every new discriminatory voting rule only after it had become effective. With section five's preclearance rule, the designated federal authorities can preempt any discriminatory voting practice by keeping it off the books in the first place." (footnotes omitted)).

186 Nw. Austin Mun. Util. Dist. No. One v. Holder (NAMUDNO), 557 U.S. 193, 223-24 (2009) ("The Court has freely acknowledged that such legislation is preventative, upholding it based on the view that the Reconstruction Amendments give Congress the power both to remedy and to deter violation of rights guaranteed thereunder by prohibiting a somewhat broader swath of conduct, including that which is not itself forbidden by the [Fifteenth] Amendment's text." (internal quotation marks omitted)); see also Pitts, supra note 81, at 615 (arguing the importance of section 5's deterrent effect). 
elderly, and youth voters. ${ }^{187}$ The power of preclearance allows jurisdictions to avoid many of these issues. As the events in Pennsylvania evidence, waiting until after the law is enacted is problematic. The confusion that ensued after the bill's passage due to its application in the April 2012 presidential primary and the subsequent judicial battle from April to October before the preliminary injunction was finally ordered ${ }^{188}$ made it very difficult to mitigate the negative impact of the restrictive law. On Election Day, many reports surfaced that election officials continued to ask for voter ID although it was not required. ${ }^{189}$

While the Texas law remained in limbo after the Department of Justice denied preclearance and was not exercised during the presidential election, ${ }^{190}$ the public service announcements and information campaign in Pennsylvania and the various applications of the enjoined law created confusion and caused some voters to lose the opportunity to vote. ${ }^{191}$ Moreover, the valuable ability to preempt discriminatory voting laws before application is crucial to preventing widespread discrimination before it starts. Certainly, these measures help to preserve and protect the rights of all voters and avoid unnecessary damage to the democratic process through confusion over whether a new requirement is in effect.

Many states, both covered and noncovered, continue to pass voter ID and other restrictive laws. ${ }^{192}$ Only a studied and intense con-

187 See supra Part II.A.2.

188 See supra Part II.A.2.

189 See, e.g., Ryan J. Reilly, Turmoil Follows as Pennsylvania Voter ID Law Meets Reality, TPM (Nov. 6, 2012, 3:55 PM), http://tpmmuckraker.talkingpointsmemo.com/2012/11/pennsylvania_voter_id_election_day.php (reporting that persons were asked for ID and turned away from the polls if they could not produce proper documentation).

190 At least one prominent report surfaced of a poll worker asking for a photo ID, but that issue was corrected and the voter was allowed to on vote a regular ballot. The incident was apparently the product of a misinformed poll worker rather than a systemic state approach. Texas, unlike Pennsylvania, did not put out an official public announcement regarding the need for voter ID or the ability to ask for ID even though a court had enjoined the requirement. See Wayne Slater, Voter ID Law Is on Hold, But Some Poll Workers Might Ask for Photo Anyway, Dall. Morning News (Oct. 29, 2012, 11:02 PM), http://www.dallasnews.com/news/columnists/ wayne-slater/20121029-wayne-slater-voter-id-law-is-on-hold-but-some-poll-workers-might-askfor-photo-anyway.ece.

191 Bill Turque, Pa. Voter Ads Draw Groups' Ire, WASH. Post, Oct. 20, 2012, at A3 (discussing the impact of the ongoing five million dollar voter ID ad campaign); Sophia Pearson, Tom Schoenberg \& Andrew Harris, Election Day Voting Target Voter ID, Mural of Obama, BLoOMBERG (Nov. 7, 2012, 8:07 AM), http://www.bloomberg.com/news/2012-11-06/pennsylva nia-judge-bars-voter-id-questions-outside-polls.html (noting that voters complained that they were denied the right to vote because they lacked proper ID, and that persons outside the polls were "harassing" voters and asking for ID).

192 See DANIEls, supra note 1, at 48 (charting pre- and post-Shelby County efforts); Emily 
sideration of the impact on voters prior to the implementation of such laws can prevent the type of uncertainty and confusion that resulted in many of the noncovered jurisdictions across the country. ${ }^{193}$ As explained above, the history of official discrimination in states like Texas merit a cautionary and preemptive review. ${ }^{194}$ Undoubtedly, the history of official discrimination, the existence of racially polarized voting, and the need for preemption are key elements to any law meant to combat voting discrimination.

\section{Conclusion}

Opponents of section 5 point to President Barack Obama's election as an illustration that the discrimination that section 5 was meant to protect no longer exists. ${ }^{195}$ Nonetheless, the fact that progress has been made in our society on the issue of race does not mean that Congress or the Supreme Court should eliminate section 5. ${ }^{196}$ The impact of the VRA is measurable. African Americans in particular saw a dramatic increase in voter registration and participation once barriers were removed to ensure nondiscriminatory access to the ballot. In $1966,41.7 \%$ of the total population of African Americans voted; in $2008,60.8 \%$ of the total population of African Americans voted. ${ }^{197}$ In $1966,60.2 \%$ of the total population of African Americans were registered to vote; in $2008,65.5 \%$ were registered to vote. ${ }^{198}$ The VRA has done more than open the door for African Americans. In many respects it knocked the door down.

Schultheis, Voter ID Battle Set to Rage Again, Polrico (Jan. 11, 2013, 4:59 PM), http:/www .politico.com/story/2013/01/voter-id-battle-set-to-rage-again-86080.html (listing states currently considering stricter voter laws).

193 Daniels, supra note 28 (arguing for states to require voter impact statements to assess voting legislation); Daniel P. Tokaji, If It's Broke, Fix It: Improving Voting Rights Act Preclearance, 49 How. L.J. 785, 839 n.279 (2006) (arguing for an "electoral impact statement" similar to an employment discrimination inquiry).

194 See supra Part III.A.

195 See Issacharoff, supra note 81, at 1730-31; Kunkes, supra note 23, at 373; Enbar Toledano, Comment, Section 5 of the Voting Rights Act and Its Place in "Post-Racial" America, 61 EMORY L.J. 389, 434 (2012); Abigail Thernstrom \& Stephan Thernstrom, Op-Ed., Taking Race Out of the Race: White Voters' Support for Obama Suggests a Dramatic Change in the Electorate, L.A. Times, Mar. 2, 2008, at M5; Peter Wallsten \& David G. Savage, Voting Rights Act out of Date?, L.A. Times, Mar. 18, 2009, at A1.

196 See Ansolabehere et. al., supra note 180, at 1387-88; Angela Onwuachi-Willig \& Mario L. Barnes, The Obama Effect: Understanding Emerging Meanings of "Obama" in Anti-Discrimination Law, 87 IND. L.J. 325, 348 (2012).

197 U.S. Census Bureau, Table A-1: Reported Voting and Registration by Race, Hispanic Origin, Sex, and Age Groups: November 1964 to 2012 (2012), available at http:/l www.census.gov/hhes/www/socdemo/voting/publications/historical/index.html.

198 Id. 
Other racial, ethnic, and language minorities have also greatly benefited. "[M]ore than one million foreign-born persons continue to enter the U.S. each year. . . . In 2005, 712,527 naturalization applications were processed with the U.S. Citizenship and Immigration Services-now a division of the Department of Homeland Securitygranting citizenship to more than 600,000 people." ${ }^{199}$ Each year, more than half a million foreign-born persons become United States citizens. ${ }^{200}$

The electorate is changing, and state voter ID legislation parallels the tests and devices of another era in its purpose and effect of limiting many Americans' ability to vote. ${ }^{201}$ According to the 2010 Census, a growing number of Americans are people of color. ${ }^{202}$ The gains in voter registration and election participation are directly attributable to the VRA. Referred to as the second generation of VRA accomplishments, the VRA also accounts for the almost exponential growth of minority elected officials. ${ }^{203}$ In 1970 , there were 1469 African American elected officials. ${ }^{204}$ In 2000 , there were 9040 -more than a six-fold increase. ${ }^{205}$

In this new century, growth has occurred on many levels, including in the registration rates of voters of color, as well as in the number

199 Electionline, Org, Translating the Vote: The Impact of the Language MinorITY Provision of THE Voting Rights ACt 5 (2006), available at http://www.pewtrusts.org/ uploadedFiles/wwwpewtrustsorg/Reports/Election_reform/electionline_translatingvote_1006 .pdf.

200 Id. at 13.

201 See generally Rosa Ramirez, 10 Amazing Demographic Percentages of the 2012 Election, NAT'L J. (Nov. 9, 2012, 5:56 PM), http:/www.nationaljournal.com/thenextamerica/politics/10amazing-demographic-percentages-of-the-2012-election-20121109 (finding a marked decrease in white male support and substantial support from people of color for President Obama); see also Rick Ungar, Top 5 Lessons of the 2012 Election-The Last Hurrah for Old White Men, Forbes (Nov. 7. 2012, 10:11 AM), http://www.forbes.com/sites/rickungar/2012/11/07/top-5-lessons-of-the2012-election-the-last-hurrah-for-old-white-men/ (showing that President Obama lost white men, but had solid support amongst minorities which carried him to victory).

202 See, e.g., Press Release, U.S. Census Bureau, 2010 Census Shows America's Diversity (Mar. 24, 2011), available at http://www.census.gov/newsroom/releases/archives/2010_census/ cb11-cn125.html (reporting that the Hispanic population accounted for more than half of the increase in the United States population and that the Asian race grew faster than any other at forty-three percent between 2000 and 2010).

203 See Pamela S. Karlan, The Rights to Vote: Some Pessimism About Formalism, 71 TEx. L. REv. 1705, $1724 \mathrm{n} .83$ (1993) (referring to the focus on section 2 litigation and eliminating at-large elections as a second generation of the VRA).

204 David A. Bositis, Joint Ctr. for Political \& Econ. Studies, Black Elected OfFicials: A Statistical Summary 5 (2000), available at http://www.jointcenter.org/publica tions1/publication-PDFs/BEO-pdfs/BEO-00.pdf.

205 Id. 
of minority elected officials. ${ }^{206}$ Many of the increases occurred on the municipal level, where section 5 tends to have the greatest impact. ${ }^{207}$ The continuation of this growth is threatened if section 5 is eliminated as a protective measure for minority citizens and their access to the voting booth.

Indeed, the protection that section 5 provides is very important in continuing the progress that has been celebrated over the past fifty years. One needs only to be reminded that this nation has in the past removed protective measures to ensure free and fair access to the ballot box at a time of great progress only to witness the return of widespread disenfranchisement following the federal government's abandonment of Reconstruction. ${ }^{208}$ The Supreme Court has considered this dilemma. During the NAMUDNO oral argument, when Justice Kennedy asked the Solicitor General's representative whether section 5 required states to surrender power to Congress, he replied:

[T]his isn't any sort of surrendering of power. [Section 5] was justified because of the record of discrimination. South Carolina v. Katzenbach, Justice Kennedy, I don't quite think said that defiance was the precondition; rather it found that the onerous amount of case-by-case litigation itself wasn't enough. And I would caution this Court because this Court has had examples before in which the historical record looked good at a narrow moment in time. If we think back 100 years to Reconstruction, 95 percent of African-Americans in franchise, 600 black members in the State legisla-

206 In a Jet article on African American elected officials, Eddie N. Williams, president of the Joint Center for Political and Economic Studies, stated:

The past three decades have been the most dynamic period for Black elected officials in terms of growth, gender and age diversity, and political clout .... When the first roster was published in 1970 , Shirley Chisholm was the only Black female in Congress and there were only two Black mayors of major cities. Today, there are 15 Black female congressional representatives and 47 big-city Black mayors.

Black Elected Officials Increased Six-Fold Since 1970: Study, JeT, Apr. 15, 2002, at 4-5.

207 Bositis, supra note 205, at 6 ("The largest categorical increase . . . was in the judicial and law enforcement area, which saw an increase of 40 positions, a 4.0 percent rise. Significant increases also occurred among county level officials (32 or 3.5 percent) and among municipal officeholders (35 or 0.8 percent)."); see also U.S. Census Bureau, Statistical Abstract of THE UNITED STATES 255 tbl.403 (2007), available at http://www.census.gov/prod/2006pubs/ 07statab/election.pdf (reporting black elected officials by office, 1970 to 2001, and state, 2001). Statewide success for minority candidates, on the other hand, has remained largely stagnant. Janai S. Nelson, Defining Race: The Obama Phenomenon and the Voting Rights Act, 72 ALB. L. REV. 899, 901 (2009).

208 See Eric Foner, Reconstruction: AmericA's Unfinished Revolution, 1863-1877, at 575-80 (Perennial 2002) (1988) (discussing efforts to dismantle the gains made and the end of Reconstruction). 
tures, 8 black members of Congress, 8 black justice[s] in the South Carolina Supreme Court. Things looked good, and that led this Court in the civil rights cases over Justice Harlan's lone dissent to say the era of special protection was over. ${ }^{209}$

Should the Supreme Court decide to dismantle section 5, this country could enter into a season similar to post-Reconstruction where previous gains were erased. ${ }^{210}$

With the demise of section 4, Congress should use the opportunity to expand its reach and require voter impact statements or other evaluative measures to preserve voting protections and progress. Section 2 of the Act cannot serve this purpose because it is reactive. Often, as in Pennsylvania, the harm is done once the legislation is passed and enacted. Section 5 freezes the legislation until it has undertaken a thorough and studied review. While this country has enjoyed select years of great progress, ${ }^{211}$ the elimination of a seminal statute could send this country careening into a downward spiral where disenfranchising legislation is commonplace and efforts to challenge those laws are too costly and time consuming to have any meaning. Under the guise of a new type of federalism that protects states' rights, ${ }^{212}$ an old type of disenfranchisement would result. Yes, Bull Connor may in fact be dead, ${ }^{213}$ but racial discrimination in voting continues to live.

209 NAMUDNO Transcript, supra note 16 , at $41-42$ (emphasis added).

210 See generally FONER, supra note 208.

211 Duncan Currie, The Long March of Racial Progress, American (Nov. 5, 2008), http:// www.american.com/archive/2008/november-11-08/the-long-march-of-racial-progress/; Melissa Harris-Lacewell, Commentary: Racial Progress is Far From Finished, CNN (June 5, 2009, 10:51 AM), http://www.cnn.com/2009/LIVING/07/07/lacewell.post.racial/. See generally BARACK Obama and African American Emponerment: The Rise of Black America's New LEADERSHIP (Manning Marable \& Kristen Clarke eds., 2009).

212 Wasserburger, supra note 90 , at 431 ("Over the course of nearly twenty years, the Rehnquist Court developed a unique jurisprudence that was simultaneously 'conservative' and 'activist.' This activism cannot be overstated, since the Rehnquist Court overturned more acts of Congress than all previous Supreme Courts combined." (footnotes and internal quotation marks omitted)).

213 Theophilus Eugene "Bull" Connor was the Commissioner of Public Safety in Birmingham, Alabama in the 1960 s and is synonymous with violence against nonviolent civil rights participants, including women and children. Eugene "Bull" Connor, PBS, http://www.pbs.org/wgbh/ americanexperience/freedomriders/people/eugene-bull-connor (last visited Sep. 7, 2013). 